\title{
Geochemical Modeling of Water-Rock Interaction Processes in the Pollino National Park
}

\author{
C. Apollaro $\mathbb{D},{ }^{1}$ I. Fuoco $\mathbb{D}$, ${ }^{1}$ L. Bloise $\mathbb{D}^{\circ},{ }^{2}$ E. Calabrese $\mathbb{D},{ }^{2}$ L. Marini $\mathbb{D},{ }^{1,3}$ G. Vespasiano $\mathbb{D},{ }^{1}$ \\ and F. Muto ${ }^{1}{ }^{1}$ \\ ${ }^{1}$ Department of Biology, Ecology and Earth Sciences (DiBEST), University of Calabria, Via Ponte Bucci, Cubo 15B, \\ 87036 Arcavacata di Rende, Italy \\ ${ }^{2}$ UNESCO Geopark Office Pollino National Park Authority, Complesso Monumentale S.M. della Consolazione 85038 Rotonda, Italy \\ ${ }^{3}$ Steam Srl, Via Ponte a Piglieri 8, 56121 Pisa, Italy
}

Correspondence should be addressed to I. Fuoco; ilaria.fuoco@unical.it

Received 20 October 2020; Revised 3 December 2020; Accepted 11 December 2020; Published 11 January 2021

Academic Editor: Francesco Frondini

Copyright $(2021$ C. Apollaro et al. This is an open access article distributed under the Creative Commons Attribution License, which permits unrestricted use, distribution, and reproduction in any medium, provided the original work is properly cited.

This work is aimed at reconstructing the water-rock interaction processes controlling the geochemical characteristics of the shallow or relatively shallow groundwaters of the Pollino National Park, based on the data acquired for 105 water samples from local springs. Reaction path modeling of rock dissolution was carried out in a purely stoichiometric mode for the main lithotypes cropping out in the study area, that is, limestone, Mg-limestone, dolomite, serpentinite, Al-silicate fraction of calcschist, and carbonate fraction of calcschist. Reaction path modeling was carried out in a purely stoichiometric mode, considering the rocks of interest as materials of known stoichiometry and unknown thermodynamic properties. Calculations were carried out assuming a closed system for secondary solid phases whereas an open system was assumed for gases, $\mathrm{O}_{2}(\mathrm{~g})$ and $\mathrm{CO}_{2}(\mathrm{~g})$. Comparison of the results of geochemical modeling and the analytical data acquired for the groundwaters of the Pollino National Park shows that concentrations of major solutes, $\mathrm{SiO}_{2}, \mathrm{Li}, \mathrm{Al}$, and $\mathrm{Fe}$ of the different chemical types of waters, are explained by the dissolution of pertinent lithotypes. Moreover, the detected concentrations of $\mathrm{Al}, \mathrm{Cl}, \mathrm{F}, \mathrm{NO}_{3}$, and $\mathrm{SO}_{4}$ are within the threshold values recommended by WHO.

\section{Introduction}

The water-rock interaction process controls the physical and chemical-mineralogical transformations of all rock types and consequently the release of dissolved constituents to groundwaters (e.g., [1-4]). The resulting concentrations of major solutes in groundwaters depend on the chemical features of the initial rainwater, the geological setting, and the extent of the water-rock interaction process, which is related to the residence time in the aquifer system. When the groundwaters travel along their hydrogeological path from the recharge to discharge areas, diverse chemical reactions take place, including (i) dissolution-precipitation reactions, (ii) ion exchange (adsorption/desorption) processes, and (iii) redox reactions [5]. These processes, often occurring simultaneously, can be predicted by means of the geochemical modeling or more precisely via the reaction path modeling of water-rock interaction.

Reaction path modeling is a powerful geochemical tool proposed by Helgeson and coworkers in the late 1960s. [6] described the relationships of the irreversible water-rock mass transfer processes on the basis of the fundamental principles of thermodynamics and chemical kinetics. Helgeson and coworkers created PATHI, the first software code for reaction path modeling, and used it to predict different geochemical processes (e.g., [7]). Afterwards, several software packages were developed, such as EQ3/6 [8], SOLVEQ/CHILLER [9], and PHREEQC [10]. Today, using these software packages, it is possible to investigate several processes of geochemical interest, including weathering (e.g., [11-29]). The study of the rock-to-water release of chemical components and of the chemical evolution of groundwaters allows 
one to widen also the knowledge of complex hydrogeological systems.

Because of its large extension over northern Calabria and southern Basilicata regions and its peculiar geological setting, the Pollino National Park hosts a complex hydrogeological system comprising several aquifers, each one with its own geological, hydrogeological, and hydrogeochemical characteristics. In this paper, the main aquifers of the Pollino National Park were studied performing the reaction path modeling of rock dissolution for six different lithotypes cropping out in the study area, which are limestones, Mg-limestones, dolomites, serpentinites, Al-silicate fraction of calcschists, and carbonate fraction of calcschists. This geochemical modeling exercise was carried out adopting an innovative approach, that is, allowing the precipitation of a few secondary solid phases only, namely, opal-CT (low-temperature disordered cristobalite with intergrowth of tridymite layers) or chalcedony, amorphous or crystalline $\mathrm{Al}(\mathrm{OH})_{3}$, and amorphous or crystalline Fe(III)-oxy-hydroxide (HFO). In this way, it was possible to reproduce the whole range of alkalinities measured in local groundwaters, while this target would not have been achieved by allowing the precipitation of carbonate minerals.

Afterwards, the theoretical trends of rock dissolution were compared with the experimental data of 105 groundwaters sampled in the Pollino National Park area and it was ascertained that the concentrations of major solutes, $\mathrm{SiO}_{2}$, $\mathrm{Li}, \mathrm{Al}$, and $\mathrm{Fe}$ of local groundwaters, are satisfactorily explained by the dissolution of the considered lithotypes, thus proving the effectiveness not only of the reaction path modeling but also of the adopted approach concerning the secondary solid phases. We are convinced that this approach can also be exported to other areas.

\section{Geological and Hydrogeological Background}

The Pollino National Park area is part of the southern Apennine fold-and-thrust belt. It is formed by a fold-and-thrust belt-foredeep system that has recorded the east-directed thrust transport and the development and deformation of progressively younger turbiditic deposits to the east. The geology of the area includes a Paleogene Subduction Complex (the Calabro-Lucanian Flysch Unit or the Liguride Complex of Southern Italy), the Middle Miocene foreland strata of the Cilento Group and younger sequences, and the Mesozoic to Miocene carbonate platform and slope (inner Alburni-Cervati-Pollino Units and the Monti della Maddalena Unit); the Campano-Lucanian Ranges, including the Mesozoic to Upper Miocene deep-sea sequences of the Lagonegro and Sicilide Units, the outer platform sequences (Monte Alpi Unit), and the Miocene foreland strata; the Lucanian-Apulia lowland, including the Pliocene to Quaternary clastics; and the Apulian Swell, a Mesozoic to Quaternary carbonate platform [30-34].

The Meso-Cenozoic carbonate successions of the southern Apennines are in contact with the uplifted crystalline rocks of the northern Calabrian Terranes [35-36] (through a regional extensive shear zone identified as the Pollino Line [37-40]).
According to some authors, the stratigraphic and structural lineaments of the area showed the occurrence of main imbricate units; from bottom to top, they are as follows: the metamorphic Lungro-Verbicaro Unit, which consists of a lower terrigenous interval of Early Triassic age, made up of phyllites and metarenites with carbonate intercalations and an upper carbonatic interval. These deposits are followed by metalimestones, marly metalimestones, and dolomites [41]. Carnian layers show a significant increase of siliciclastic beds intercalated with metadolomites, metalimestones, and evaporites. The metalimestones are generally coarse and crystalline and locally exhibit stratification. On top of this lithological interval are red siliceous slates and radiolarite beds passing to coarse carbonate conglomerates and breccias, metapelites. Siliciclastic metadolomites and evaporate strata prevail to the SW, whereas to the NE, the succession is dominated by the carbonate of the Pollino Unit. This carbonate succession overthrust the Pollino-Ciagola Unit resulting in the tectonic window in the Orsomarso Mts. area. The unit comprises carbonate deposits with large and variable stratigraphic gaps occurring in these slope facies successions. The Late Triassic is almost everywhere represented by thick-bedded, white-to-light gray dolomites. The dolomites grade upward to limestones calcareous dark, well-bedded, generally cyclic limestones with characteristic fossiliferous content. They are covered by calcarenites [42] and by Miocene siliciclastic turbiditic deposits which include marls, pelites, and quartz arenites $[42,43]$.

In the northern part of the study area, carbonate units are overthrust by nappes belonging to continental and oceanic domains. Remnants of crystalline basement rocks such as gneiss and granite outcrop at the top of tectonic assemblage or result englobed in the ophiolite-bearing nappes of the Liguride Complex. The complex comprises ophiolite-bearing units made up of serpentinites, gabbros, and pillow basalts; the metamorphic Frido Unit; and the unmetamorphosed North Calabrian Unit [44]. The latter crops out in the proximity of the NE sector of the Pollino Massif, in the CalabriaLucania border area. The Frido Unit is constituted by blackish schists, metarenites, greenish quartzites, and calcschists. The rocks incorporate the ophiolitic rocks and thrust on the Calabro-Lucanian Flysch Unit [31]. This is the lowermost geometric unit of the Liguride Complex [44] and crops out extensively in the northeastern part of the area, which tectonically lies on the carbonate units. It consists of a thick alternation of gray-brown flaked shales, quartz siltites and quartz sandstones, marly calcilutites, and calcarenites. As a whole, it shows the structural and textural characteristics of a broken formation and tectonically incorporates blocks of the ophiolite-bearing rocks and relatively sedimentary cover and blocks of the Crete Nere Formation, consisting of black shales, quartz siltites, cherty limestones, and calcilutites and marly limestones with intercalations of grayish argillites. Oligocene to Miocene deposits consisting of turbiditic calcareous and terrigenous flysch have been considered together with the sedimentary succession of Jurassic-Miocene age (Figure 1).

On the top of the entire tectonic edifice rests the terrigenous succession of Upper Miocene-Pleistocene marine and continental intramountain basins $[45,46]$. 




FIgure 1: Lithological map of the Pollino National Park area. In the figure, the trace (red line) of the schematic geological section (see Figure (Figure 9) and the location of all considered samples are reported.

The fold-and-thrust system is the result of accretionary wedge overthrust and collisional processes that realized eastern and western thrust propagation $[45,47-50]$. The latest tectonic event is characterized mostly by strike-slip faulting and associated positive and negative structures [39, 51]. The fault systems (i.e., NW-SE, N-S, and NE-SW oriented) 
are responsible for the severe dissection of the mountain belt into discrete crustal blocks alternating structural high to elongated structural depressions.

The study area is characterized by hydrogeological complexes which highlight differences in terms of flow rates and depth. Throughout the area, it is possible to recognize three main hydrogeological complexes:

(i) Carbonate-dolomitic complex

(ii) Crystalline-metamorphic complex

(iii) Terrigenous-calcareous in flysch facies complex

The carbonate-dolomitic complex includes aquifers hosted in limestones, dolostones, chert-bearing limestones, and marly limestones. The complex represents one of the main sources of drinking water supplies in Calabria, Southern Italy [52-58]. These lithotypes, due to the brittle characters and the sin- and postorogenic tectonic evolution, identify a dominant fractured cleavage permeable aquifer. Moreover, due to their typical chemical composition, they are subject to karst phenomena through which the action of dissolving rainwater tends to expand the network of preexisting fractures. These characteristics promote high infiltration processes with values between $85 \%$ and $95 \%$ [52]. The main spring flow rates in the order of hundreds $1 / \mathrm{s}[59,60]$ are located in the proximity of the hydrogeological boundaries constituted of fine and impermeable deposits or along the main faults that play the role of the flow zone and/or permeability threshold [52, 59, 60].

The Liguride Units, except for the respective sedimentary covers, can be grouped in the crystalline-metamorphic complex [52]. This group, if compared with the carbonatedolomitic complex, represents a minor hydrogeological structure. The aquifers are directly linked both to the thickness of gneisses and granites (alteration) and to the state of fracturing of the rock mass. Low-grade metamorphites represent a water system conditioned by fracturing and above all by vertical lithological anisotropy.

There are also aquifers of lesser importance, represented by lithostratigraphic units included in basin sedimentary succession and flysch facies, well represented in the study area. These aquifers are affected by the alternation of fine and coarse materials and tend to give multiaquifer water systems with higher productivity in the conglomeratic-arenaceous intervals.

\section{Materials and Methods}

3.1. Water Sampling and Analysis. A total of 62 water samples from the Pollino National Park area were collected during the present study and analyzed for major components. The sampling methodologies were already described by [61-66]; however, a brief description is reported here. In the field, the physicochemical parameters like temperature, $\mathrm{pH}$, oxidation-reduction potential (Eh), and electrical conductivity (EC) were determined by using a previously calibrated multiparametric probe (Hanna Instruments HI9828) whereas total alkalinity was determined by acidimetric titration using $\mathrm{HCl} 0.05 \mathrm{~N}$ as the titrating agent and methyl orange as the indicator. Each water sample was filtered in the field via a $0.45 \mu \mathrm{m}$ pore-size membrane filter. Samples for the determination of cations, $\mathrm{SiO}_{2}$, and trace elements were acidified by the addition of pure acid $\left(1 \% \mathrm{HNO}_{3}\right)$ whereas samples for the determination of anions were stored without further treatment. The concentrations of $\mathrm{Na}^{+}, \mathrm{K}^{+}$, $\mathrm{Mg}^{2+}, \mathrm{Ca}^{2+}, \mathrm{F}^{-}, \mathrm{Cl}^{-}, \mathrm{SO}_{4}{ }^{2-}$, and $\mathrm{NO}_{3}{ }^{-}$were determined by high-performance liquid chromatography (HPLC, Dionex $\mathrm{DX} 1100)$. Some trace elements such as $\mathrm{Fe}$ and $\mathrm{Al}$ were determined by a quadrupole inductively coupled plasma-mass spectrometer (ICP-MS, PerkinElmer/SCIEX, ELAN DRC-e) with a collision reaction cell capable of reducing or avoiding the formation of polyatomic spectral interferences. Data quality was evaluated by charge balance for major ions $( \pm 10 \%)$ and by running NIST $1643 \mathrm{f}$ standard reference solution for trace elements with deviation from certified concentration below the $\pm 10 \%$. Moreover, the concentration of $\mathrm{SiO}_{2}$ was measured by means of VIS spectrophotometry. These 62 water samples were added to previous data collection provided by [67] (the reader should refer to the original work for the methods of water sampling and analysis used by authors), and all 105 samples were used in this work (Table S1 in Supplementary Materials).

3.2. Geochemical Modeling. Reaction path modeling of rock dissolution was performed using the software package EQ3/6 [8] and a revised version of the thermodynamic database of [68].

Reaction path modeling of rock dissolution was carried out in a purely stoichiometric mode, referring to the reaction progress variable, $\xi$, without any time provision, that is, leaving aside the kinetics of the irreversible water-rock mass exchanges. This means that at each $\xi$ step, a corresponding amount of the solid reactant is added to the system made up of the aqueous solution and secondary solid phases if any. The added solid reactant is dissolved, and the aqueous solution is reequilibrated with the instantaneously precipitating product phases if any [69].

Although reaction path modeling in a stoichiometric mode implies that all rock-forming minerals are assumed to dissolve at the same rate (which is surely not true), in this approach, it is not necessary to specify for the relevant minerals neither the surface areas, which are nothing but educated guesses in many cases, nor the dissolution-precipitation rates, which are constrained by laboratory experiment results often diverging from field data. To be noted also, the stoichiometric approach is reasonable for monomineralic rocks like the carbonate rocks and the serpentinites.

In the adopted approach, the rocks of interest are considered "special reactants," that is, materials of known stoichiometry and unknown thermodynamic properties [69]. Following the indications of the EQ3/6 manuals, concentrations of chemical elements in special reactants were expressed in $\mathrm{mol} / \mathrm{kg}$.

Calculations were carried out assuming a closed system for secondary solid phases. This means that the precipitating solid phases remain in the considered system and are in equilibrium with the aqueous solution for the whole duration of 
TABLE 1: Elemental composition of the six solid reactants considered in reaction path modeling of rock dissolution.

\begin{tabular}{|c|c|c|c|c|c|c|}
\hline Element & $\begin{array}{l}\text { Dolomite } \\
\mathrm{mol} / \mathrm{kg}\end{array}$ & $\begin{array}{l}\text { Mg-limestone } \\
\mathrm{mol} / \mathrm{kg}\end{array}$ & $\begin{array}{c}\text { Limestone } \\
\mathrm{mol} / \mathrm{kg}\end{array}$ & $\begin{array}{c}\text { Carbonate-calcschist } \\
\mathrm{mol} / \mathrm{kg}\end{array}$ & $\begin{array}{c}\text { Al-silicate calcschist } \\
\mathrm{mol} / \mathrm{kg}\end{array}$ & $\begin{array}{l}\text { Serpentinite } \\
\mathrm{mol} / \mathrm{kg}\end{array}$ \\
\hline $\mathrm{H}$ & - & - & - & - & - & $1.24 E+01$ \\
\hline $\mathrm{Li}$ & $2.26 E-04$ & $8.62 E-04$ & $3.92 E-04$ & $7.20 E-04$ & $9.51 E-03$ & $4.49 E-04$ \\
\hline $\mathrm{C}$ & $1.96 E+01$ & $1.87 E+01$ & $1.94 E+01$ & $7.45 E+00$ & - & - \\
\hline $\mathrm{O}$ & $3.93 E+01$ & $3.79 E+01$ & $3.93 E+01$ & $1.49 E+01$ & $2.69 E+01$ & $3.16 E+01$ \\
\hline $\mathrm{Na}$ & $6.91 E-01$ & $2.44 E-01$ & $1.58 E+00$ & $5.39 E-01$ & $4.58 E-01$ & $1.86 E+00$ \\
\hline $\mathrm{Mg}$ & $9.55 E+00$ & $1.64 E+00$ & $2.46 E-01$ & $1.64 E-01$ & $8.71 E-01$ & $9.20 E+00$ \\
\hline $\mathrm{Al}$ & $5.97 E-03$ & $1.08 E-01$ & $6.91 E-03$ & - & $4.57 E+00$ & $3.57 E-01$ \\
\hline $\mathrm{Si}$ & $4.72 E-02$ & $1.66 E-01$ & $2.12 E-01$ & - & $8.27 E+00$ & $6.25 E+00$ \\
\hline$S$ & - & - & - & - & - & $6.42 E-04$ \\
\hline $\mathrm{Cl}$ & - & - & - & - & - & $3.07 E-03$ \\
\hline K & $1.67 E-03$ & $1.72 E-02$ & $2.02 E-03$ & $3.76 E-02$ & $8.28 E-01$ & $1.12 E-03$ \\
\hline $\mathrm{Ca}$ & $9.35 E+00$ & $1.68 E+01$ & $1.76 E+01$ & $6.53 E+00$ & $1.82 E-01$ & $1.04 E-01$ \\
\hline $\mathrm{Fe}$ & $2.45 E-03$ & $1.58 E-02$ & $3.38 E-03$ & $1.43 E-01$ & $1.17 E+00$ & $1.33 E+00$ \\
\hline
\end{tabular}

the simulation. Hence, they can be redissolved if the aqueous solution becomes undersaturated.

An open system was instead assumed for gases, namely, $\mathrm{O}_{2}(\mathrm{~g})$ and $\mathrm{CO}_{2}(\mathrm{~g})$. In other terms, the system is considered to be connected to two infinitely large gas reservoirs, one of $\mathrm{O}_{2}(\mathrm{~g})$ and the other of $\mathrm{CO}_{2}(\mathrm{~g})$, which fix the partial pressure of these two gases to the chosen values. Indeed, simulations were performed at a constant temperature of $12^{\circ} \mathrm{C}, \log f_{\mathrm{CO}_{2}}$ of $-2.6 \log$ bar and $\log f_{\mathrm{O}_{2}}$ of $-25 \log$ bar.

3.2.1. The Solid Reactants. Six different solid reactants were considered: a limestone, an Mg-limestone, a dolomite, and a serpentinite, as well as the carbonate and Al-silicate endmembers of a calcschist. These six rocks were sampled in the Pollino National Park. The chemical composition was obtained by means of Scanning Electron MicroscopyEnergy-Dispersive Spectra (SEM-EDS) analysis and through $\mathrm{X}$-ray fluorescence spectroscopy (XRF) analysis performed during this study in the laboratories of DiBEST, University of Calabria, and provided by previous investigations [15, $70,71]$. The computed elemental compositions of the six solid reactants are given in Table 1.

3.2.2. The Solid Products. To keep the model to a simple level, only few oxy-hydroxides were allowed to precipitate as secondary (alteration) phases, including a silica mineral, an aluminum hydroxide, and a ferric oxy-hydroxide (HFO). Among the different silica minerals, chalcedony precipitation was allowed when the availability of $\mathrm{SiO}_{2}$ is low, that is, during the dissolution of the carbonate rocks (dolomite, Mglimestone, limestone, and the carbonate fraction of the calcschist), whereas opal-CT production was permitted when the availability of $\mathrm{SiO}_{2}$ is high, that is, during the dissolution of the serpentinite and the Al-silicate fraction of the calcschist. As a general rule, the amorphous oxy-hydroxides of $\mathrm{Al}$ and $\mathrm{Fe}(+3)$ have a higher solubility than their crystalline and higher precipitation rate as well. Owing to the lower solubil- ity, the crystalline phases should precipitate before the amorphous oxy-hydroxides, but this event usually does not take place because the precipitation kinetics of crystalline phases is slow. Owing to the lack of precipitation of the crystalline phases, the aqueous solution may become supersaturated with the amorphous phases, which precipitate readily due to their fast precipitation kinetics. Actually, the process is more complicated, comprising the reversible, rapid growth of small polymers and the subsequent formation of slowly reacting large polymers before the precipitation of ferric oxy-hydroxides (e.g., [72]). Based on these considerations, two distinct runs were performed for each solid reactant, allowing the precipitation of amorphous $\mathrm{Al}(\mathrm{OH})_{3}$ and amorphous $\mathrm{HFO}$, in a series of runs, and permitting the production of gibbsite and crystalline HFO in a separate series of simulations. Chalcedony, opal-CT, gibbsite, amorphous $\mathrm{Al}(\mathrm{OH})_{3}$, and crystalline and amorphous $\mathrm{HFO}$ were assumed to be pure minerals.

3.2.3. Initial Aqueous Solutions. The concentrations of major dissolved constituents in the initial aqueous solution were reconstructed based on the results of the chemical analyses of rainwater periodically sampled in the Cosenza area, apart from total carbonate concentration which was assumed to be constrained by the electrical charge balance. Aluminum concentration was obtained by forcing equilibrium with gibbsite. The concentration of $\mathrm{Fe}$ in rainwater, $C_{\mathrm{Fe}, \mathrm{RW}}$, was computed using the simple relation:

$$
C_{\mathrm{Fe}, \mathrm{RW}}=C_{\mathrm{Fe}, \mathrm{SW}} \cdot\left(\frac{C_{\mathrm{Cl}, \mathrm{RW}}}{C_{\mathrm{Cl}, \mathrm{SW}}}\right) \text {, }
$$

where $C_{\mathrm{Cl}, \mathrm{RW}}$ and $C_{\mathrm{Cl}, \mathrm{SW}}$ are the average $\mathrm{Cl}$ concentration of rainwater and seawater, respectively, and $C_{\mathrm{Fe}, \mathrm{SW}}$ is the concentration of $\mathrm{Fe}$ in average seawater. The adopted average seawater composition is from [73]. Equation (1) is based on 
TABLE 2: Elemental composition of the initial aqueous solution for $T=12^{\circ} \mathrm{C}, \mathrm{pH}=6.80$, and $\mathrm{Eh}=837 \mathrm{mV}$.

\begin{tabular}{lcc}
\hline Element & $\mathrm{mg} / \mathrm{kg} \cdot \mathrm{sol}$ & $\mathrm{mol} / \mathrm{kg}$ \\
\hline $\mathrm{Al}$ & $4.73 E-05$ & $1.75 E-09$ \\
$\mathrm{C}$ & $5.10 E+00$ & $4.25 E-04$ \\
$\mathrm{Ca}$ & $6.00 E+00$ & $1.50 E-04$ \\
$\mathrm{Cl}$ & $1.70 E+00$ & $4.80 E-05$ \\
$\mathrm{Fe}$ & $7.00 E-04$ & $1.25 E-08$ \\
$\mathrm{~K}$ & $1.80 E-01$ & $4.60 E-06$ \\
$\mathrm{Li}$ & $1.00 E-05$ & $1.44 E-09$ \\
$\mathrm{Mg}$ & $7.00 E-01$ & $2.88 E-05$ \\
$\mathrm{~N}$ & $2.26 E-01$ & $1.61 E-05$ \\
$\mathrm{Na}$ & $1.50 E+00$ & $6.52 E-05$ \\
$\mathrm{~S}$ & $1.07 E+00$ & $3.33 E-05$ \\
$\mathrm{Si}$ & $1.17 E+00$ & $4.16 E-05$ \\
\hline
\end{tabular}

a reasonable approximation since rainwaters in near-coastal regions, like the Pollino National Park, are essentially heavily diluted seawater [74]. The $\log P_{\mathrm{CO} 2}$ of the initial aqueous solution was assumed to be -2.6 , which is close to the mean value of spring waters. Having specified both the $P_{\mathrm{CO} 2}$ and the total carbonate concentration, $\mathrm{pH}$ is fixed and turns out to be 6.80 . The redox potential was constrained by the log $P_{\mathrm{O} 2}$ of -0.678 , which is the mean atmospheric value. Results of the EQ3 run for the initial aqueous solution are given in Table 2.

3.2.4. The Refurbishing of the Thermodynamic Database. As already mentioned above, reaction path modeling of rock dissolution was carried out referring to the thermodynamic database of [68], which was modified adopting the solubilities of chalcedony and opal-CT given by [75]. Moreover, the equilibrium constant values of the dissolution reaction of the oxy-hydroxides of $\mathrm{Al}$ and $\mathrm{Fe}^{3+}$ were adjusted to suitably selected values in order to bracket the measured total concentrations of these dissolved constituents.

\section{Results and Discussion}

4.1. Water Chemistry. The considered spring waters have outlet temperatures ranging from 4.5 to $17.1^{\circ} \mathrm{C}$, with mean $11.1^{\circ} \mathrm{C}$, median $11.4^{\circ} \mathrm{C}$, and standard deviation $2.3^{\circ} \mathrm{C}$. These different outlet temperatures are partly controlled by the distinct elevation, from 212 to $1536 \mathrm{~m}$ asl, and partly reflect the different sampling periods. These groundwaters are scarcely mineralized, as indicated by the relatively low values of the electrical conductivity, varying from 67 to $841 \mu \mathrm{S} / \mathrm{cm}$, with mean $426 \mu \mathrm{S} / \mathrm{cm}$, median $402 \mu \mathrm{S} / \mathrm{cm}$, and standard deviation $140 \mu \mathrm{S} / \mathrm{cm}$. The highest conductivities were recorded for the three samples of the sulfide-bearing Abatemarco springs (codes 16, 17, and A24), which are also characterized by unusual low Eh S(-2)-S(0) values, -139 to $-150 \mathrm{mV}$ (calculated by geochemical modeling), and chemistry. The Eh values measured by means of the Pt electrode for all the other springs are in the interval +34 to $+305 \mathrm{mV}$, with mean $+154 \mathrm{mV}$, median $+157 \mathrm{mV}$, and standard deviation $65 \mathrm{mV}$. These relatively high redox potentials are indicative of prevailingly oxidizing conditions, as expected for shallow waters. However, it is unlikely that measured Eh values are controlled by one of the two electroactive redox couples to which the Pt electrode is sensitive, i.e., the $\mathrm{Fe}(+2)-\mathrm{Fe}(+3)$ and $\mathrm{S}(-2)-$ $\mathrm{S}(0)$ systems [76], owing to the low concentrations of iron and reduced sulfur species in these aqueous solutions. The $\mathrm{pH}$ values oscillate around the neutrality conditions, from 6.83 to 8.86 , with mean 7.65, median 7.6, and standard deviation 0.40 . The logarithm of the computed $\mathrm{CO}_{2}$ partial pressure, which depends largely on $\mathrm{pH}$, varies from -3.65 to -1.60 , with mean -2.39 , median -2.37 , and standard deviation 0.42 (all in log bar). Eighty-three samples have log $P_{\mathrm{CO} 2}$ values within the range of worldwide soils, -2.70 to $-1.40 \mathrm{log}$ bar [77], indicating that $\mathrm{CO}_{2}$ is chiefly contributed to water by processes occurring in soils, such as the decay of organic matter and root respiration. The remaining twenty-two samples have lower $\log P_{\mathrm{CO} 2}$ values, but all except one are higher than the mean atmospheric $\log P_{\mathrm{CO} 2},-3.50 \log$ bar. Therefore, it is likely that these $\operatorname{low} \log P_{\mathrm{CO} 2}$ values are controlled by gas exchanges between the aqueous solutions and the atmosphere.

As shown by the triangular diagram of major anions (Figure 2(a)), bicarbonate is the prevailing anion in all the waters apart from the three samples of the sulfide-bearing Abatemarco springs (codes 16, 17, and A24), which have comparable concentrations of $\mathrm{SO}_{4}$ and $\mathrm{HCO}_{3}$. The almostubiquitous prevalence of bicarbonate suggests that the mineralization of most waters is chiefly controlled by rock dissolution driven by conversion of $\mathrm{CO}_{2}$ into $\mathrm{HCO}_{3}^{-}$ion.

In the triangular diagram of main cations (Figure 2(b)), all the water samples are distributed near the axis connecting the vertices of $\mathrm{Ca}$ and $\mathrm{Mg}$, since the sum of the relative concentrations of $\mathrm{Na}$ and $\mathrm{K}$ is less than $20 \mathrm{eq} \%$ apart from sample A21. This sample has the lowest conductivity, $67 \mu \mathrm{S} / \mathrm{cm}$, but unusually higher concentrations of $\mathrm{Na}$ and $\mathrm{Cl}, 25$ and $24 \mathrm{eq} \%$, respectively, which are probably related to the marine-atmospheric component. In other words, sample A21 is rainwater scarcely modified by water-rock interaction. Based on the $\mathrm{Ca} /(\mathrm{Ca}+\mathrm{Mg})$ molar ratio, it is possible to recognize thirty calcic waters, with values higher than 0.75 , sixtythree calcic-magnesian waters, with values in the interval 0.50 to 0.75 , and twelve magnesian waters with values lower than 0.50 .

Taking into account the indications provided by the two triangular diagrams of Figure 2, the considered spring waters were provisionally ascribed to the following three chemical types: $\mathrm{Ca}-\mathrm{HCO}_{3}, \mathrm{Ca}(\mathrm{Mg})-\mathrm{HCO}_{3}$, and $\mathrm{Mg}-\mathrm{HCO}_{3}$.

The diagram of Figure 2(b) also shows the expected compositions for (i) dissolution of calcite, coinciding with the $\mathrm{Ca}$ vertex, (ii) dissolution of dolomite, located along the axis connecting the vertices of $\mathrm{Ca}$ and $\mathrm{Mg}$ at equal distance from both vertices, and (iii) dissolution of magnesite, coinciding with the $\mathrm{Mg}$ vertex. Therefore, one might be tempted to conclude that the $\mathrm{Ca}-\mathrm{HCO}_{3}$ waters originate by prevailing dissolution of calcite and subordinate dissolution of dolomite, the $\mathrm{Ca}(\mathrm{Mg})-\mathrm{HCO}_{3}$ waters are generated by predominant dissolution of dolomite accompanied by minor dissolution of 


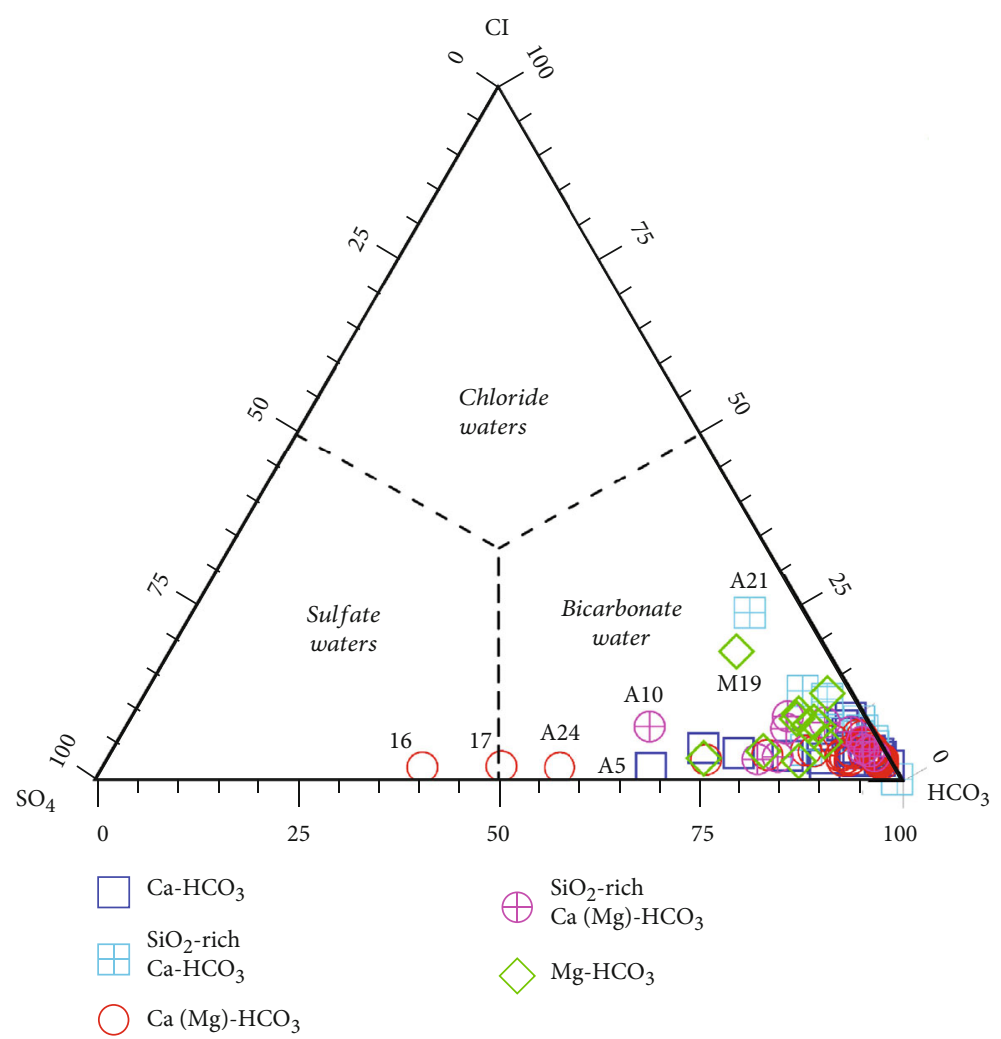

(a)



(b)

Figure 2: Triangular diagrams of the main anionic (a) and cationic (b) constituents for the spring waters of the Pollino National Park (concentration in equivalent units). 


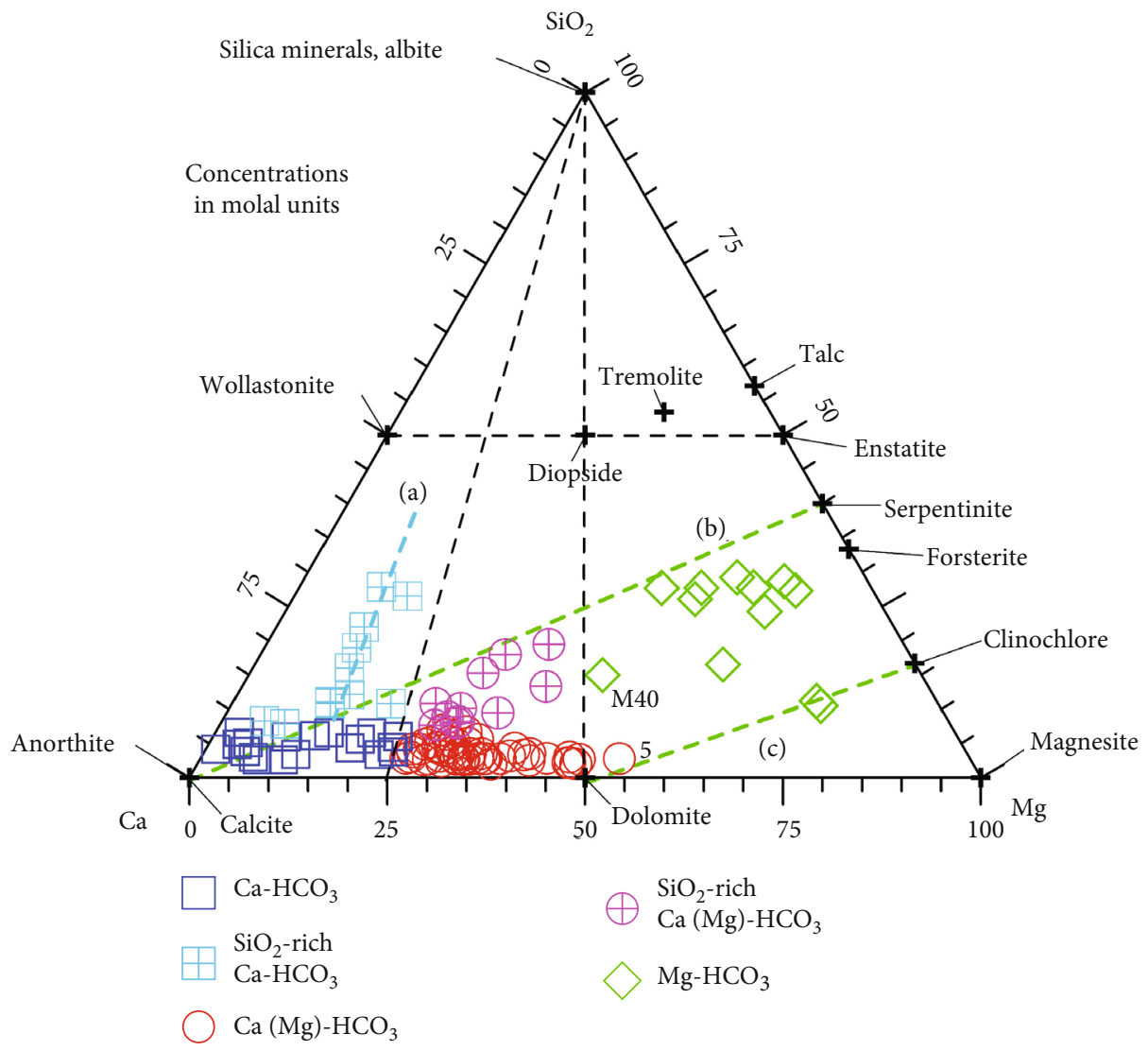

Figure 3: Triangular diagram of $\mathrm{Ca}-\mathrm{Mg}-\mathrm{SiO}_{2}$, for the spring waters of the Pollino National Park (concentrations in molal units).

calcite, and the $\mathrm{Mg}-\mathrm{HCO}_{3}$ waters are produced by dissolution of magnesite and dolomite in different proportions. These inferences may be right for the $\mathrm{Ca}-\mathrm{HCO}_{3}$ and $\mathrm{Ca}(\mathrm{Mg})-\mathrm{HCO}_{3}$ waters originated by the interaction of meteoric waters with carbonate rocks only, but they are probably wrong for the $\mathrm{Ca}-\mathrm{HCO}_{3}$ and $\mathrm{Ca}(\mathrm{Mg})-\mathrm{HCO}_{3}$ waters deriving by the interaction of meteoric waters with both carbonate rocks and $\mathrm{Al}$-silicate rocks or with mixed rocks like the calcschists, comprising a carbonate fraction and an $\mathrm{Al}$-silicate fraction, or even with $\mathrm{Al}$-silicate rocks only, given the fact that they often contain veins of calcite or dolomite. To be noted also, the $\mathrm{Ca}-\mathrm{HCO}_{3}$ and $\mathrm{Ca}(\mathrm{Mg})-\mathrm{HCO}_{3}$ waters somehow related to $\mathrm{Al}$-silicate rocks are expected to be rather common because these lithotypes extend over vast sectors of the Pollino National Park area (Figure 1). Furthermore, the $\mathrm{Mg}-\mathrm{HCO}_{3}$ waters are unlikely to be produced by the dissolution of magnesite, since monomineralic rock bodies exclusively made up of magnesite (or almost so), analogous to limestones and dolomites, are rare [78, 79].

The waters probably affected by the dissolution of Alsilicate rocks were selected based on values of the TIS/SiO ratio lower than 50 , where TIS is the acronym of total ionic salinity, representing the sum of the concentrations of major cations and anions, in meq/kg, and $\mathrm{SiO}_{2}$ concentration is expressed in $\mathrm{mmol} / \mathrm{kg}$. Most of the springs discharging these waters are found in areas where Al-silicate rocks crop out. After this further classification step, the spring waters were finally attributed to one of the following five chemical types:
$\mathrm{Ca}-\mathrm{HCO}_{3}, \mathrm{SiO}_{2}$-rich $\mathrm{Ca}-\mathrm{HCO}_{3}, \mathrm{Ca}(\mathrm{Mg})-\mathrm{HCO}_{3}, \mathrm{SiO}_{2}$-rich $\mathrm{Ca}(\mathrm{Mg})-\mathrm{HCO}_{3}$, and $\mathrm{Mg}-\mathrm{HCO}_{3}$.

To elucidate the role played by the dissolution of Alsilicate rocks, it is advisable to take into consideration the triangular diagram of $\mathrm{Ca}-\mathrm{Mg}-\mathrm{SiO}_{2}$ (Figure 3), in which the chemical characteristics of the spring waters of interest are compared with the compositions expected for dissolution not only of carbonate minerals but also of several Sibearing minerals, which are probably present in local $\mathrm{Al}$ silicate rocks, such as quartz, talc, enstatite, serpentine, forsterite, clinochlore, tremolite, diopside, wollastonite, anorthite, and albite. The dissolution reactions of considered minerals are based on the following two hypotheses [80]. (1) The water-rock interaction processes, in which carbonate and silicate minerals are dissolved, can be assimilated to acidbase titrations, in which the minerals act as bases, while aqueous $\mathrm{CO}_{2}$ is the acid that controls the process and is converted into $\mathrm{HCO}_{3}{ }^{-}$ion. (2) Aluminum released by the dissolution of the primary $\mathrm{Al}$-silicates, such as clinochlore and plagioclases, is entirely incorporated into precipitating kaolinite, although other secondary Al-bearing solid phases may form instead of it, leading to different water compositions [16].

Even though several other Si-bearing minerals might be present in local rocks in addition to those considered so far, the latter ones are sufficient for explaining the chemistry of the water samples of interest. In fact, in Figure 3, most Sirich $\mathrm{Ca}-\mathrm{HCO}_{3}$ waters are positioned along trend (a), which is controlled by the dissolution of quartz and/or other silica 


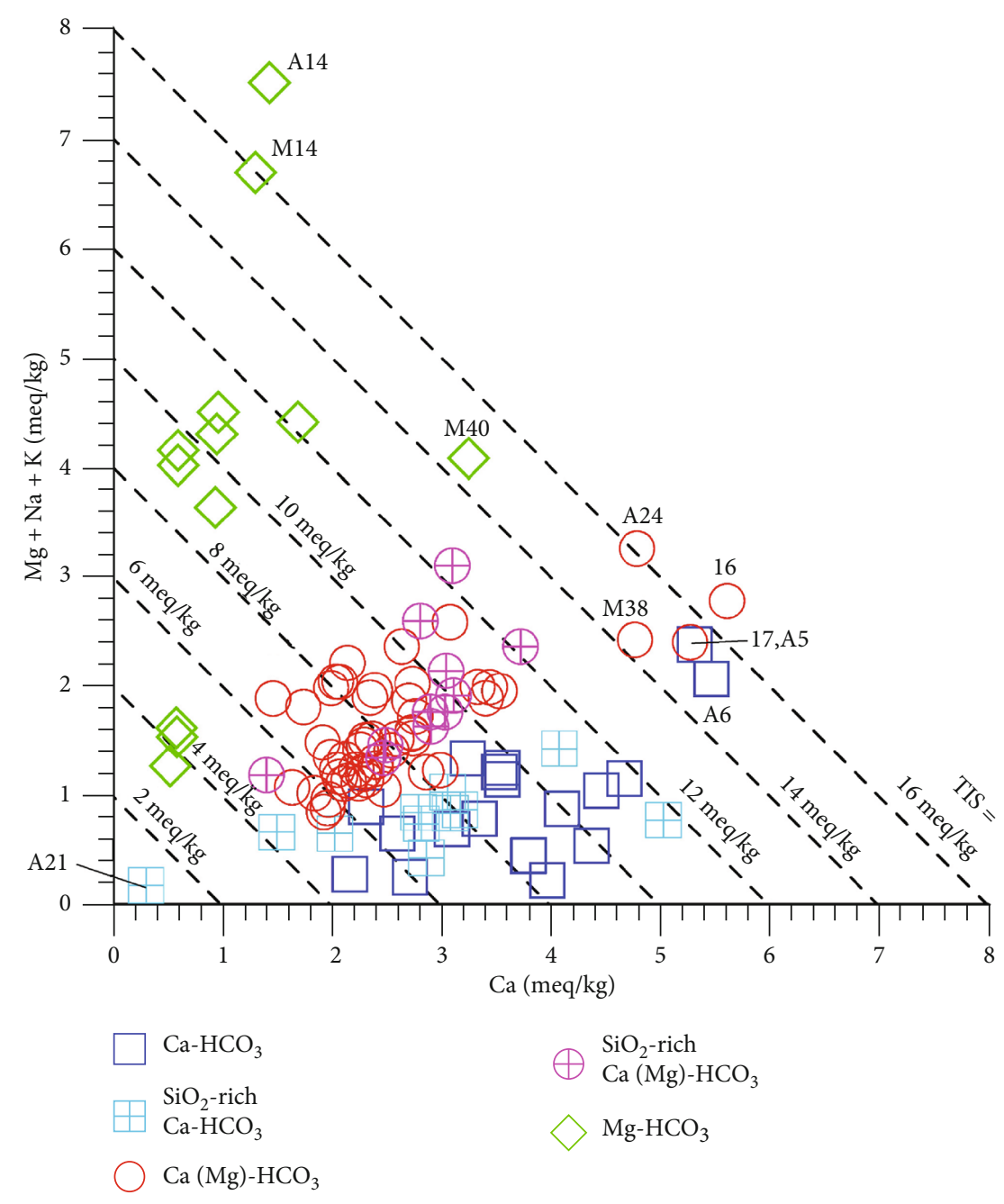

Figure 4: Correlation diagram of $\mathrm{Ca}$ vs. $\mathrm{Mg}+\mathrm{Na}+\mathrm{K}$ for the spring waters of the Pollino National Park in which the isolines of total ionic salinity (iso-TIS lines) are reported.

minerals and/or albite, suggesting that these waters probably interact, at least partially, with acid rocks or, alternatively, with chert-bearing limestones. The Si-rich $\mathrm{Ca}(\mathrm{Mg})-\mathrm{HCO}_{3}$ waters and the $\mathrm{Mg}-\mathrm{HCO}_{3}$ waters are positioned between the serpentine-calcite tie line (b) and the clinochloredolomite tie line (c), suggesting that their chemical characteristics are probably controlled by the dissolution of these four minerals. However, the possible contribution of forsterite dissolution cannot be excluded because it would determine water compositions intermediate between those controlled by serpentine and clinochlore dissolution. Also, magnesite dissolution represents a plausible option, at least for the $\mathrm{Mg}-\mathrm{HCO}_{3}$ waters characterized by high $\mathrm{Mg} / \mathrm{SiO}_{2}$ ratios. The Si-rich $\mathrm{Ca}(\mathrm{Mg})-\mathrm{HCO}_{3}$ waters probably interact, at least partially, with mafic or ultramafic rocks.

Since the triangular plots of Figures 2 and 3 do not convey any information on total ionic salinity, this parameter is inspected by means of the correlation diagram of $\mathrm{Ca}$ vs. $\mathrm{Mg}$ $+\mathrm{Na}+\mathrm{K}$ (Figure 4), in which the TIS values of the considered spring waters can be appreciated by comparing the position of each sample with the lines of slope -1 which are iso-TIS lines (see [81] for further details). It turns out that most spring waters have TIS of 3.6 to $12.9 \mathrm{meq} / \mathrm{kg}$, irrespective of the chemical type they belong to, apart from sample A21 which has TIS of $1 \mathrm{meq} / \mathrm{kg}$ only and nine samples with TIS of 14.4 to $18.4 \mathrm{meq} / \mathrm{kg}$, including the sulfide-bearing Abatemarco springs (codes 16, 17, and A24). Finally, the acquired chemical information showed that the concentrations of $\mathrm{Al}$, $\mathrm{Cl}, \mathrm{F}, \mathrm{NO}_{3}$, and $\mathrm{SO}_{4}$ are within the threshold values recommended by the World Health Organization (WHO) [82] which established the guidelines for drinking water quality.

4.2. Reaction Path Modeling. Results of reaction path modeling onto precipitating HFO are reported adopting alkalinity as a proxy for the reaction progress variable [16]. This choice is based on the fact that progressive rock dissolution can be considered a sort of acid-base titration, in which the base is the rock and the acid is $\mathrm{CO}_{2(\mathrm{aq})}$, which is converted to $\mathrm{HCO}_{3}{ }^{-}$ion, as pointed out long ago by [80].

4.2.1. The Precipitating Solid Phases. Based on the simulations performed in this work, the precipitating solid phases during the gradual dissolution of the limestone, the Mg-limestone, the dolomite, and the serpentinite, as well as the 
TABle 3: Precipitating solid phases during the simulations of the progressive dissolution of the limestone, the Mg-limestone, the dolomite, and the serpentinite, as well as the carbonate and Al-silicate endmembers of the calcschist considered in this work.

\begin{tabular}{lcc}
\hline Dissolving rock & Type of precipitating minerals & Precipitating minerals \\
\hline Limestone & Amorphous & $\mathrm{Al}(\mathrm{OH})_{3}(\mathrm{am}), \mathrm{HFO}(\mathrm{am})$ \\
Limestone & Crystalline & $\mathrm{Gibbsite}, \mathrm{HFO}(\mathrm{cr})$ \\
Mg-limestone & Amorphous & $\mathrm{Al}(\mathrm{OH})_{3}(\mathrm{am}), \mathrm{HFO}(\mathrm{am})$ \\
Mg-limestone & Crystalline & $\mathrm{Gibbsite,} \mathrm{HFO}(\mathrm{cr})$ \\
Dolomite & Amorphous & $\mathrm{Al}(\mathrm{OH})_{3}(\mathrm{am})$ \\
Dolomite & Crystalline & $\mathrm{Gibbsite,} \mathrm{HFO}(\mathrm{cr})$ \\
Calcschist, Al-silicate endmember & Amorphous & $\mathrm{Al}(\mathrm{OH})_{3}(\mathrm{am}), \mathrm{HFO}(\mathrm{am})$, opal-CT \\
Calcschist, Al-silicate endmember & Crystalline & $\mathrm{Gibbsite}, \mathrm{HFO}(\mathrm{cr})$, opal-CT \\
Calcschist, carbonate endmember & Amorphous & $\mathrm{HFO}(\mathrm{am})$ \\
Calcschist, carbonate endmember & Crystalline & $\mathrm{HFO}(\mathrm{cr})$ \\
Serpentinite & Amorphous & $\mathrm{Al}(\mathrm{OH})_{3}(\mathrm{am}), \mathrm{HFO}(\mathrm{am})$, opal-CT \\
Serpentinite & Crystalline & $\mathrm{Gibbsite,} \mathrm{HFO(cr),} \mathrm{opal-CT}$ \\
\hline
\end{tabular}



(a)

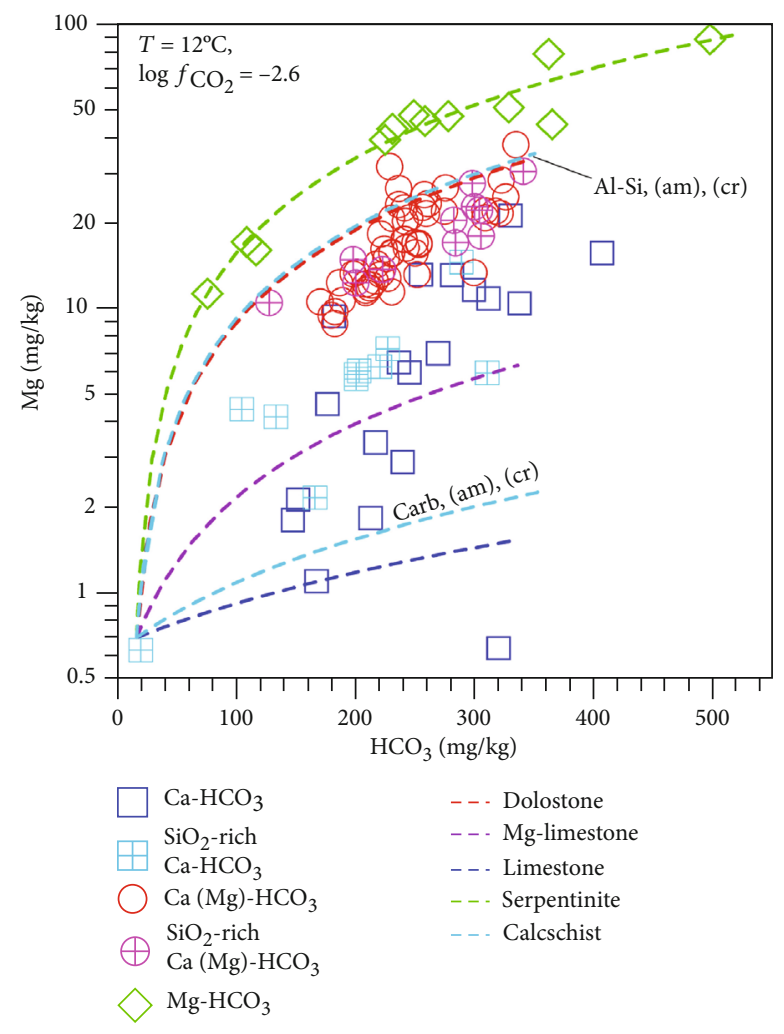

(b)

FIgure 5: Correlation diagrams of alkalinity (expressed in $\mathrm{mg} \mathrm{HCO}_{3} / \mathrm{kg}$ ) vs. (a) calcium and (b) magnesium during the progressive dissolution of different rocks (see legend) according to the simulations elaborated in this work.

carbonate and $\mathrm{Al}$-silicate endmembers of the calcschist are summarized in Table 3.

Table 3 shows that amorphous or crystalline HFO forms as secondary minerals in all the simulations, except the dolomite dissolution with possible precipitation of amorphous minerals, in which the aqueous solution does not attain satu- ration with amorphous $\mathrm{HFO}$. Amorphous $\mathrm{Al}(\mathrm{OH})_{3}$ and gibbsite precipitate in all the simulations apart from the dissolution of the carbonate endmember of the calcschist, which was assumed to be Al- and Si-free. Opal-CT is a solid phase only in the simulations in which the serpentinite and the Al-silicate endmember of the calcschist are dissolved. 


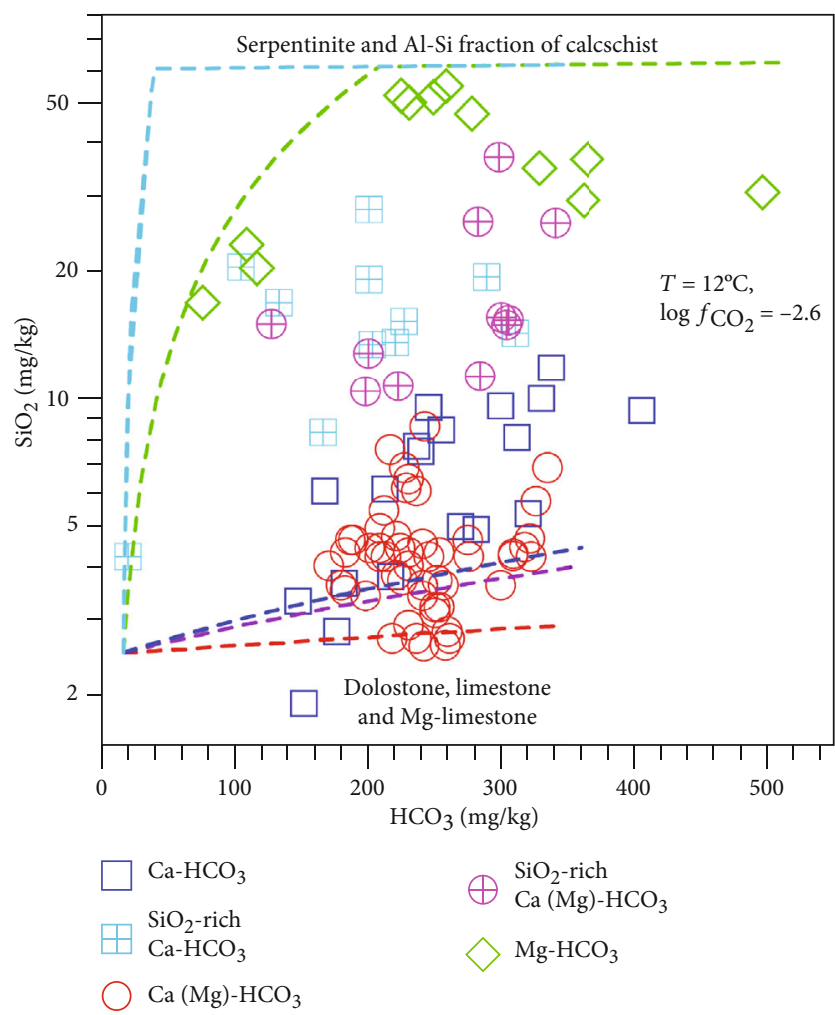

(a)

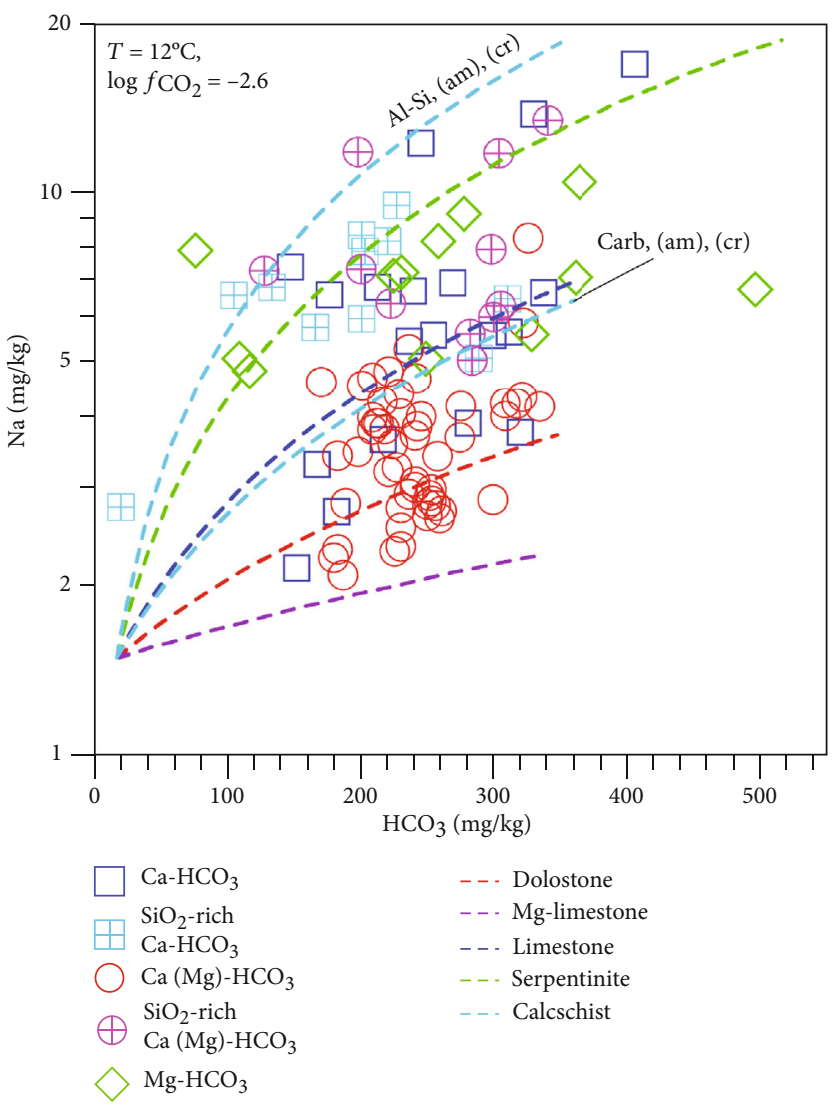

(b)

FIGURE 6: Correlation diagrams of alkalinity (expressed in $\mathrm{mg} \mathrm{HCO}_{3} / \mathrm{kg}$ ) vs. (a) silica and (b) sodium during the progressive dissolution of different rocks (see legend) according to the simulations elaborated in this work.

Chalcedony precipitation never takes place, although it was allowed during the dissolution of the carbonate rocks, i.e., the dolomite, the Mg-limestone, the limestone, and the carbonate endmember of the calcschist. Evidently, the aqueous solution remains undersaturated with respect to chalcedony during the dissolution of these carbonate rocks.

\subsubsection{The Aqueous Solutions}

(1) Calcium and Magnesium. In the correlation diagram of alkalinity vs. calcium (Figure 5(a)), (i) the $\mathrm{Ca}-\mathrm{HCO}_{3}$ waters and the $\mathrm{SiO}_{2}$-rich $\mathrm{Ca}-\mathrm{HCO}_{3}$ waters are found along or close to the dissolution curves of the limestone, the Mg-limestone, and the carbonate endmember of the calcschist, which are superimposed on each other, whereas (ii) the $\mathrm{Ca}(\mathrm{Mg})$ $\mathrm{HCO}_{3}$ waters and the $\mathrm{SiO}_{2}$-rich $\mathrm{Ca}(\mathrm{Mg})-\mathrm{HCO}_{3}$ waters are situated between the previous curves and that describing the dissolution of the dolomite (apart from a few exceptions). Moreover, all these waters are situated far from the dissolution curve of the Al-silicate endmember of the calcschist. This spread of sample points indicates that the $\mathrm{Ca}-\mathrm{HCO}_{3}, \mathrm{SiO}_{2}$-rich $\mathrm{Ca}-\mathrm{HCO}_{3}, \mathrm{Ca}(\mathrm{Mg})-\mathrm{HCO}_{3}$, and $\mathrm{SiO}_{2}$-rich $\mathrm{Ca}(\mathrm{Mg})-\mathrm{HCO}_{3}$ waters are produced through the dissolution of different carbonate rocks, in variable proportions, whereas the dissolution of the Al-silicate endmember of the calcschist does not seem to contribute significantly to the mineralization of these waters. The $\mathrm{Mg}-\mathrm{HCO}_{3}$ waters are positioned above the serpentinite dissolution curve, probably due to the presence of small amounts of calcite, which is readily dissolved, inside these rocks and/or related soils.

In contrast to what was observed in the previous plot, the dissolution curves of the limestone, the Mg-limestone, and the carbonate endmember of the calcschist are clearly separated in the correlation diagram of alkalinity vs. magnesium (Figure 5(b)) and are all located well below the dolomite dissolution curve. As expected, the $\mathrm{Ca}(\mathrm{Mg})-\mathrm{HCO}_{3}$ and $\mathrm{SiO}_{2}-$ rich $\mathrm{Ca}(\mathrm{Mg})-\mathrm{HCO}_{3}$ waters are found close to the dolomite dissolution curve, whereas the $\mathrm{Ca}-\mathrm{HCO}_{3}$ and $\mathrm{SiO}_{2}$-rich $\mathrm{Ca}$ $\mathrm{HCO}_{3}$ waters (apart from a single exception) have lower $\mathrm{Mg}$ concentrations and are situated below the dolomite dissolution curve and above the limestone dissolution curve. This spread of sample points confirms that all these waters are originated through the dissolution of these distinct carbonate rocks, in variable proportions. The $\mathrm{Mg}-\mathrm{HCO}_{3}$ waters are situated along the serpentinite dissolution curve or close to it, as expected. All in all, there is a very good correspondence between the theoretical rock dissolution curves and the analytical data of $\mathrm{Ca}, \mathrm{Mg}$, and alkalinity for the groundwaters of interest. 


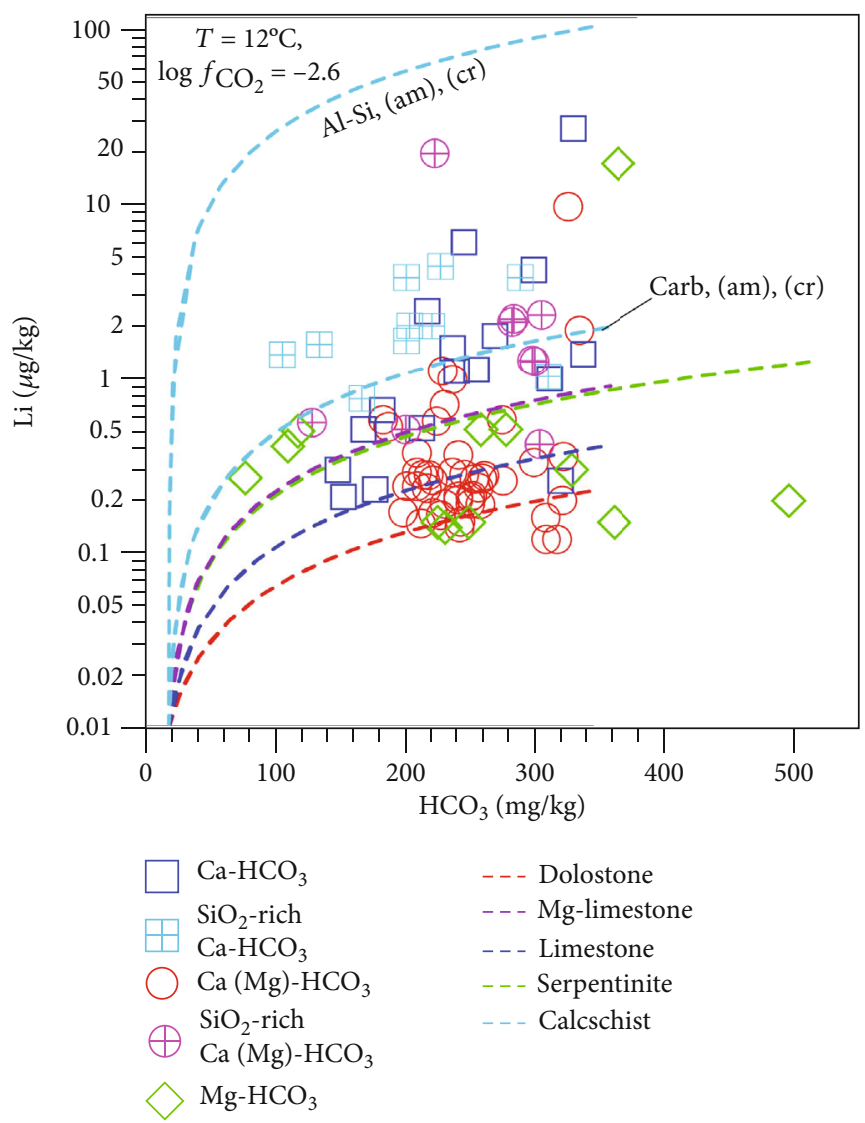

(a)

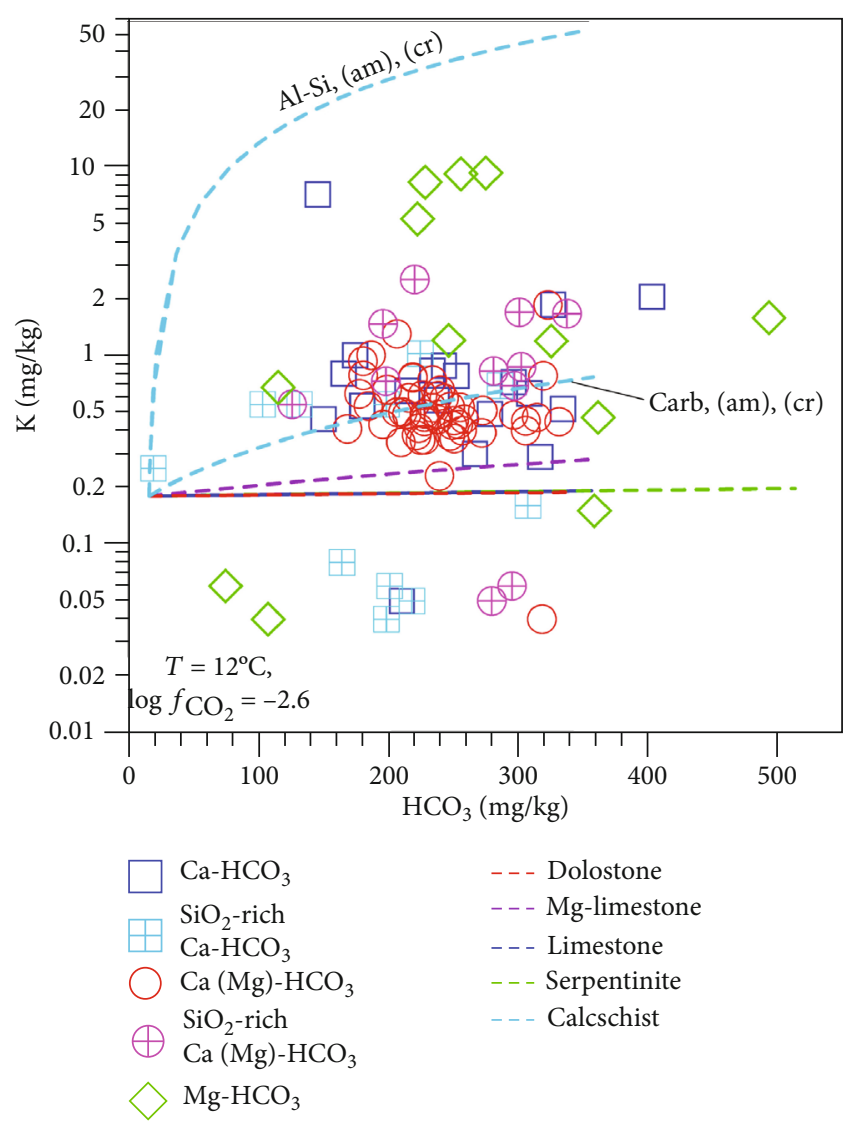

(b)

FIGURE 7: Correlation diagrams of alkalinity (expressed in $\mathrm{mg} \mathrm{HCO}_{3} / \mathrm{kg}$ ) vs. (a) lithium and (b) potassium during the progressive dissolution of different rocks (see legend) according to the simulations elaborated in this work.

(2) Silica and Sodium. Relatively low concentrations of both silica and sodium are expected for dissolution of the carbonate rocks, whereas comparatively high concentrations of both silica and sodium are predicted for dissolution of the Al-silicate endmember of the calcschist and the serpentinite, as shown by the location of the dissolution curves of these different lithotypes in the correlation diagrams of alkalinity vs. silica (Figure 6(a)) and alkalinity vs. sodium (Figure 6(b)).

A major difference is that $\mathrm{Na}$ is expected to have conservative behavior during the dissolution of all the considered rocks, whereas $\mathrm{SiO}_{2}$ is expected to have conservative behavior during the dissolution of the carbonate rocks but to be fixed by saturation with respect to a silica mineral during the dissolution of the Al-silicate endmember of the calcschist and the serpentinite. Saturation with opal-CT was imposed in the latter two cases, but this condition actually determines the uppermost dissolved $\mathrm{SiO}_{2}$ concentration, which is $59.0 \mathrm{mg} / \mathrm{kg}$ at $12^{\circ} \mathrm{C}$. Alternatively, attainment of saturation with respect to less soluble silica minerals, such as chalcedony or $\alpha$-cristobalite or moganite, is possible, with corresponding $\mathrm{SiO}_{2}$ concentrations of $11.8,18.8$, and $26.7 \mathrm{mg} / \mathrm{kg}$, respectively, at $12^{\circ} \mathrm{C}$.

Consistent with the location of the rock dissolution curves, most $\mathrm{Ca}-\mathrm{HCO}_{3}$ and $\mathrm{Ca}(\mathrm{Mg})-\mathrm{HCO}_{3}$ waters have
$\mathrm{SiO}_{2}$ and $\mathrm{Na}$ concentrations lower than $\mathrm{SiO}_{2}$-rich $\mathrm{Ca}$ $\mathrm{HCO}_{3}, \mathrm{SiO}_{2}$-rich $\mathrm{Ca}(\mathrm{Mg})-\mathrm{HCO}_{3}$, and $\mathrm{Mg}-\mathrm{HCO}_{3}$ waters. However, a few $\mathrm{Ca}-\mathrm{HCO}_{3}$ waters have Na concentrations higher than expected values possibly due to high contributions of the marine-atmospheric aerosols or limited anthropogenic contamination.

(3) Lithium and Potassium. The correlation diagrams of alkalinity vs. lithium (Figure 7(a)) and alkalinity vs. potassium (Figure 7(b)) show that the highest concentrations of these two alkali metals are expected for dissolution of the $\mathrm{Al}$ silicate endmember of the calcschist whereas lower concentrations are foreseen for dissolution of the carbonate rocks and the serpentinite. However, the spread of the analytical data is not consistent or is not entirely consistent with these theoretical predictions, suggesting that the variability of $\mathrm{Li}$ and $\mathrm{K}$ concentrations in the rocks of interest might be larger than indicated by the available analytical data. Furthermore, the limited effects of anthropogenic contamination cannot be ruled out for potassium.

(4) Aluminum and Iron. Most groundwaters of the Pollino National Park are found between the curves of rock dissolution accompanied by precipitation of amorphous $\mathrm{Al}$ hydroxide and the curves of rock dissolution with concurrent production of crystalline gibbsite, indicating that $\mathrm{Al}$ 


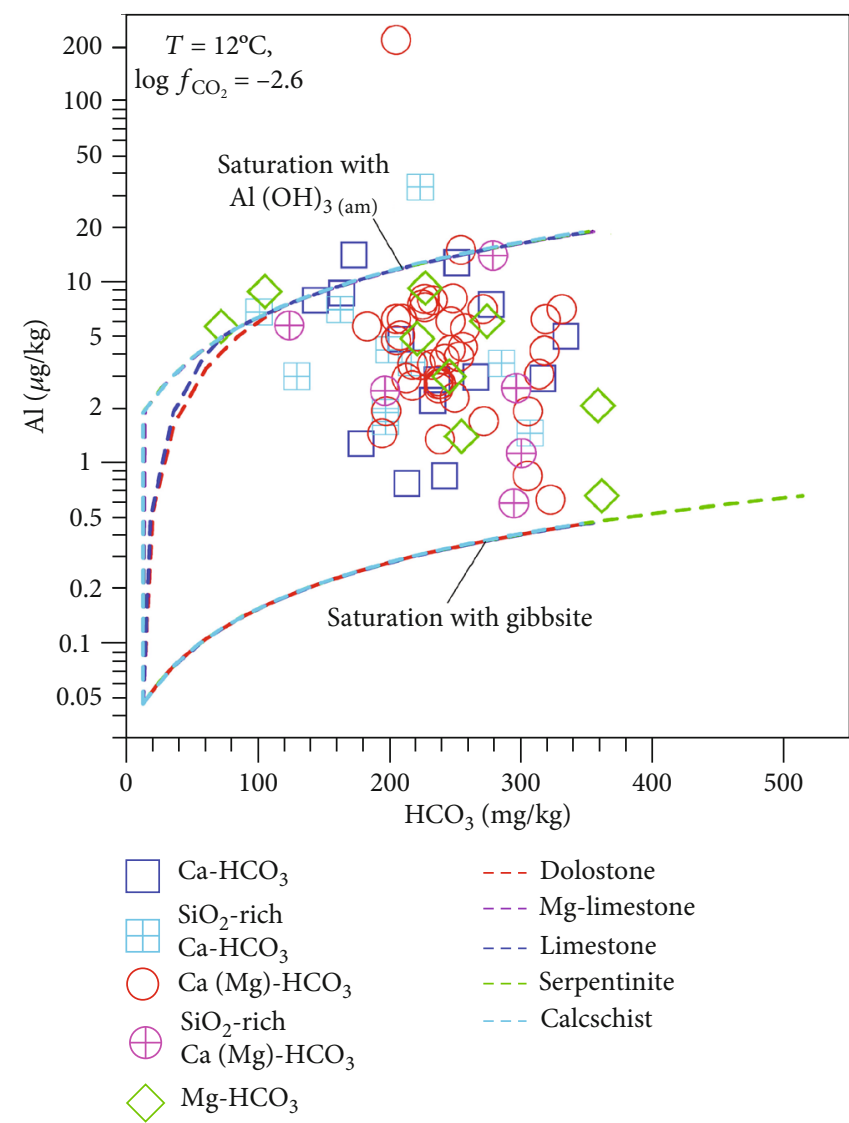

(a)



(b)

FIGURE 8: Correlation diagrams of alkalinity (expressed in $\mathrm{mg} \mathrm{HCO}_{3} / \mathrm{kg}$ ) vs. (a) aluminum and (b) iron during the progressive dissolution of different rocks (see legend) according to the simulations elaborated in this work.

concentration is controlled by saturation with amorphous $\mathrm{Al}$ hydroxide or crystalline gibbsite or Al oxy-hydroxide of intermediate crystallinity, irrespective of the dissolving lithotype (Figure 8(a)). These Al-controlling solid phases are early-precipitating, persisting solid phases during waterrock interaction. Similarly, most waters of interest are positioned between the curves of rock dissolution accompanied by precipitation of amorphous HFO and the curves of rock dissolution with concurrent generation of crystalline HFO, suggesting that $\mathrm{Fe}$ concentration is governed by saturation with amorphous or crystalline HFO or HFO of intermediate crystallinity (Figure 8(b)). The saturation with HFO is attained almost immediately during the dissolution of the Al-silicate and carbonate endmembers of the calcschist and the serpentinite, whereas it is achieved at progressively later stages during the dissolution of the $\mathrm{Mg}$-limestone, the limestone, and the dolomite, respectively.

4.3. Geological and Hydrogeological Evidence. In the Pollino National Park, the main springs are generally localized in the proximity of hydrogeological boundaries that play the role of the flow zone or permeability threshold. This important point that was already mentioned in Section 2 (e.g., Figure 1) can be appreciated in the schematic geological section of Figure 9 showing the stratigraphic relationships among different lithotypes and the water discharge areas of each chemical type.

In detail, $\mathrm{Ca}-\mathrm{HCO}_{3}$ and $\mathrm{Ca}(\mathrm{Mg})-\mathrm{HCO}_{3}$ waters are generally related to main outcrops of the Triassic dolostones and limestones and are often found close to the contact between these rocks and different lithotypes of low permeability. Both fracturing and karsting largely control the development of these carbonate aquifers often discharging through springs of high flow rates, especially near the main hydrogeological contacts. Moreover, the water transfers from limestone to dolostone reservoirs or vice versa can easily occur due to karsting and fracturing. The performed reaction path modeling and the available analytical data show clearly the occurrence of this exchange process among aquifers hosted in different carbonate rocks. In fact, there is no break of continuity in the spread of $\mathrm{Ca}-\mathrm{HCO}_{3}$ and $\mathrm{Ca}(\mathrm{Mg})-\mathrm{HCO}_{3}$ waters in all the previously examined diagrams, due to the interactions of these waters with different carbonate rocks, i.e., limestone, $\mathrm{Mg}$-limestone, and dolostone. These waters are also characterized by small concentrations of $\mathrm{SiO}_{2}$ (Figure 6(a)) which probably derive from Si-bearing minerals present as impurities in carbonate rocks or from a minor, time-limited interaction with the siliceous-clastic component of the Calabro-Lucano Flysch Unit (clayey-calcareous arenaceous complex) and/or the Frido Unit (peliticschist and calcschist), 


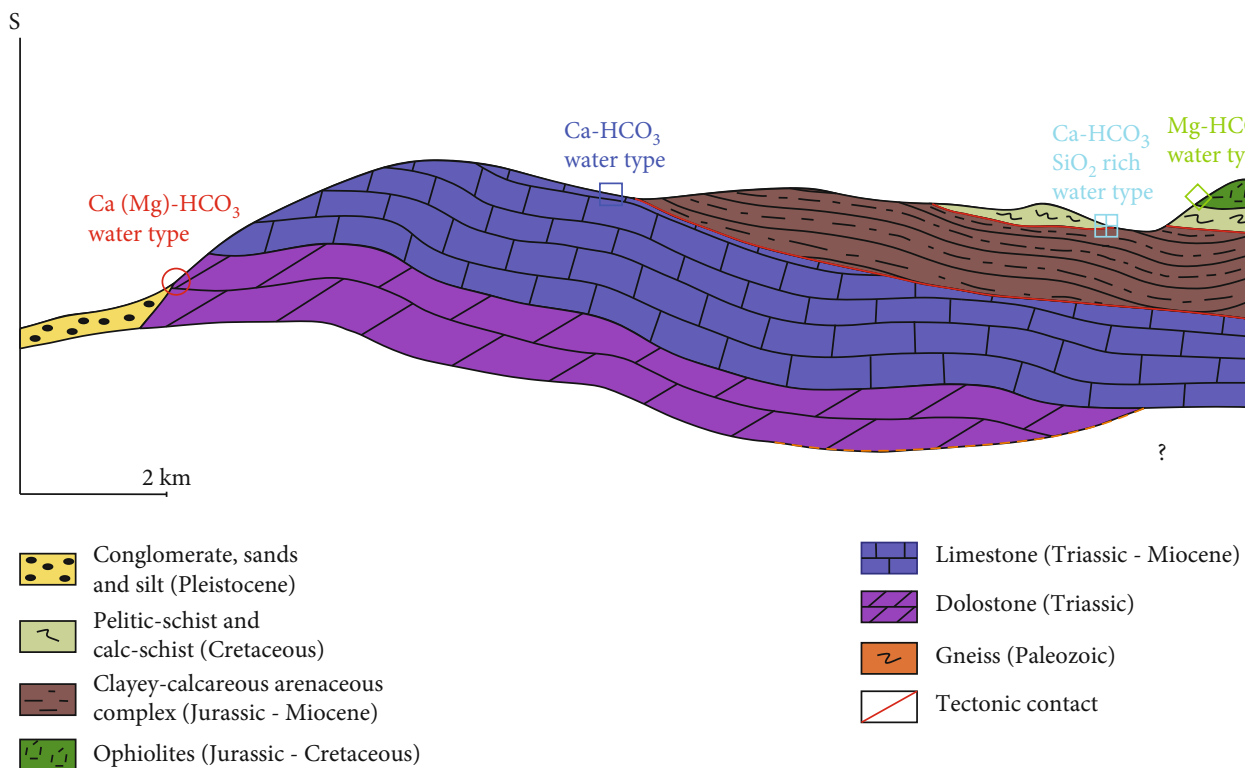

FIGURE 9: Schematic geological section (the trace is reported in Figure 1) representing the main units cropping out in the study area and the typical emergency area for each chemical type.

both widely present in the Pollino National Park area in a stratigraphically higher position than the carbonate complex (Figure 9). In fact, the $\mathrm{SiO}_{2}$ concentrations explained by the theoretical dissolution trends of the carbonate rocks are lower than those by the analytical data, suggesting that $\mathrm{Si}$ sources external to the carbonate rocks have to be invoked to explain the analytical data.

The $\mathrm{SiO}_{2}$-rich $\mathrm{Ca}-\mathrm{HCO}_{3}$ and $\mathrm{Ca}(\mathrm{Mg})-\mathrm{HCO}_{3}$ waters are influenced to a considerable extent by the dissolution of chert, quartz, and/or other Si-bearing minerals present in the rocks of the Calabro-Lucano Flysch Unit (clayey-calcareous arenaceous complex) and the Frido Unit (peliticschist and calcschist) (Figure 9), in line with the theoretical dissolution trends of the Al-silicate endmember of the calcschist. Finally, the chemical characteristics of the $\mathrm{Mg}-\mathrm{HCO}_{3}$ waters, generally emerging from serpentinite rocks, are controlled almost exclusively by the dissolution of this lithotype.

\section{Conclusions}

Reaction path modeling of rock dissolution was performed for the main lithotypes cropping out in the Pollino National Park, including limestone, Mg-limestone, dolomite, serpentinite, Al-silicate fraction of calcschist, and carbonate fraction of calcschist. Geochemical modeling was carried out adopting an innovative approach, that is, allowing the precipitation of a few secondary solid phases only, namely, opal-CT or chalcedony, amorphous or crystalline $\mathrm{Al}(\mathrm{OH})_{3}$, and amorphous or crystalline $\mathrm{FeOOH}$. In this way, it was possible to reproduce the whole range of alkalinities measured in local groundwaters, while this target would not have been achieved by allowing the precipitation of carbonate minerals.

Through the comparison of the theoretical water composition resulting from the dissolution of the considered rocks with the corresponding chemical characteristics of 105 local groundwaters, it was ascertained that major solutes, $\mathrm{SiO}_{2}$,
$\mathrm{Li}, \mathrm{Al}$, and $\mathrm{Fe}$, are satisfactorily explained by the dissolution of the considered lithotypes and the detected concentrations do not exceed the threshold values established by WHO. This fact proves the effectiveness of both the reaction path modeling, in general, and, in particular, the approach adopted to deal with secondary solid phases.

The results of reaction path modeling were validated by hydrogeological evidence which highlights the occurrence of multiple interactions between the considered groundwaters and the several lithotypes. $\mathrm{Ca}-\mathrm{HCO}_{3}$ and $\mathrm{Ca}(\mathrm{Mg})$ $\mathrm{HCO}_{3}$ waters result from the dissolution of carbonate rocks with minor, time-limited interaction with the siliceous-clastic component of the Calabro-Lucano Flysch Unit and/or the Frido Unit, which are both widely present in the Pollino National Park area in a stratigraphically higher position than the carbonate complex. The dissolution of these lithotypes exerts strong control over the chemical characteristics of the $\mathrm{SiO}_{2}$-rich $\mathrm{Ca}-\mathrm{HCO}_{3}$ and $\mathrm{SiO}_{2}$-rich $\mathrm{Ca}(\mathrm{Mg})-\mathrm{HCO}_{3}$ waters, whereas the chemistry of $\mathrm{Mg}-\mathrm{HCO}_{3}$ waters is controlled almost exclusively by the dissolution of serpentinite rocks.

\section{Data Availability}

The manuscript is a data self-contained article, whose results were obtained from the laboratory analysis, and the entire data is presented within the article. However, if any additional information is required, these are available from the corresponding author upon request to the e-mail ilaria.fuoco@unical.it.

\section{Conflicts of Interest}

The authors declare that they have no known competing financial interests or personal relationships that could have appeared to influence the work reported in this paper. 


\section{Acknowledgments}

The work has been supported by the collaboration agreement relating to the project "Acque minerali e rocce: Ogni acqua, la sua roccia." CODICE CUP D18D19005690001 was funded by UNESCO GeoparkOffice Pollino National Park Authority.

\section{Supplementary Materials}

Physical-chemical parameters of studied groundwaters. (Supplementary Materials)

\section{References}

[1] C. Apollaro, F. Perri, E. Le Pera, I. Fuoco, and T. Critelli, "Chemical and minero-petrographical changes on granulite rocks affected by weathering processes," Frontiers of Earth Science, vol. 13, no. 2, pp. 247-261, 2019.

[2] C. Apollaro, F. Perri, L. Borrelli, and T. Caloiero, "The role of water-rock interaction processes in soil formation: geochemical, mineralogical, geomorphological, and engineeringgeological aspects," Geofluids, vol. 2019, Article ID 8453136, 4 pages, 2019.

[3] F. Perri, F. Ietto, E. Le Pera, and C. Apollaro, "Weathering processes affecting granitoid profiles of Capo Vaticano (Calabria, southern Italy) based on petrographic, mineralogic and reaction path modelling approaches," Geological Journal, vol. 51, no. 3, pp. 368-386, 2016.

[4] F. Perri, F. Scarciglia, C. Apollaro, and L. Marini, "Characterization of granitoid profiles in the Sila Massif (Calabria, southern Italy) and reconstruction of weathering processes by mineralogy, chemistry, and reaction path modeling," Journal of Soils and Sediments, vol. 15, no. 6, pp. 1351-1372, 2015.

[5] L. Elango and R. Kannan, "Chapter 11. Rock-water interaction and its control on chemical composition of groundwater," Concepts and Applications in Environmental Geochemistry, vol. 5, pp. 229-243, 2007.

[6] H. C. Helgeson, "Evaluation of irreversible reactions in geochemical processes involving minerals and aqueous solutions-I. Thermodynamic relations," Geochimica et Cosmochimica Acta, vol. 32, no. 8, pp. 853-877, 1968.

[7] H. C. Helgeson, T. H. Brown, A. Nigrini, and T. A. Jones, "Calculation of mass transfer in geochemical processes involving aqueous solutions," Geochimica et Cosmochimica Acta, vol. 34, no. 5, pp. 569-592, 1970.

[8] T. W. Wolery and R. L. Jarek, Software User's Manual. EQ3/6, Version 8.0, Sandia National Laboratories - U.S. Dept. of Energy Report, 2003.

[9] M. H. Reed, "Calculation of multicomponent chemical equilibria and reaction processes in systems involving minerals, gases and an aqueous phase," Geochimica et Cosmochimica Acta, vol. 46, no. 4, pp. 513-528, 1982.

[10] D. L. Parkhurst and C. A. J. Appelo, "Description of input and examples for PHREEQC version 3- a computer program for speciation, batch-reaction, one-dimensional transport, and inverse geochemical calculations," U.S. Geological Survey Techniques and Methods, Book 6, Chap. A43, p. 497, 2013, available only at http://pubs. https://pubs.usgs.gov/tm/06/ a $43 / /$.

[11] C. Apollaro, "Geochemical modeling of water-rock interaction in the granulite rocks of lower crust in the Serre Massif (South- ern Calabria, Italy)," Geofluids, vol. 2019, Article ID 5602648, 11 pages, 2019.

[12] C. Apollaro, I. Fuoco, G. Brozzo, and R. De Rosa, "Release and fate of $\mathrm{Cr}$ (VI) in the ophiolitic aquifers of Italy: the role of Fe (III) as a potential oxidant of Cr (III) supported by reaction path modelling," Sci. Total Environ., vol. 660, pp. 1459-1471, 2019.

[13] C. Apollaro, L. Marini, T. Critelli et al., "Modeling of the impact of dolomite and biotite dissolution on vermiculite composition in a gneissic shallow aquifer of the Sila Massif (Calabria, Italy)," Applied Geochemistry, vol. 35, pp. 297-311, 2013.

[14] C. Apollaro, L. Marini, T. Critelli, and R. De Rosa, "The standard thermodynamic properties of vermiculites and prediction of their occurrence during water-rock interaction," Applied Geochemistry, vol. 35, pp. 264-278, 2013.

[15] C. Apollaro, L. Marini, T. Critelli et al., "Investigation of rockto-water release and fate of major, minor, and trace elements in the metabasalt-serpentinite shallow aquifer of Mt. Reventino (CZ, Italy) by reaction path modelling," Applied Geochemistry, vol. 26, no. 9-10, pp. 1722-1740, 2011.

[16] C. Apollaro, M. Accornero, L. Marini, D. Barca, and R. De Rosa, "The impact of dolomite and plagioclase weathering on the chemistry of shallow groundwaters circulating in a granodiorite-dominated catchment of the Sila Massif (Calabria, Southern Italy)," Applied Geochemistry, vol. 24, no. 5, pp. 957-979, 2009.

[17] C. Apollaro, L. Marini, and R. De Rosa, "Use of reaction path modeling to predict the chemistry of stream water and groundwater: a case study from the Fiume Grande Valley (Calabria, Italy)," Environmental Geology, vol. 51, no. 7, pp. 1133-1145, 2007.

[18] C. Apollaro, L. Marini, R. De Rosa, P. Settembrino, F. Scarciglia, and G. Vecchio, "Geochemical features of rocks, stream sediments, and soils of the Fiume Grande Valley (Calabria, Italy)," Environmental Geology, vol. 52, no. 4, pp. 719729, 2007.

[19] S. A. Banwart, A. Berg, and D. J. Beerling, "Process-based modeling of silicate mineral weathering responses to increasing atmospheric $\mathrm{CO} 2$ and climate change," Global Biogeochemical Cycles, vol. 23, no. 4, 2009.

[20] T. Boschetti and L. Toscani, "Springs and streams of the TaroCeno Valleys (Northern Apennine, Italy): reaction path modeling of waters interacting with serpentinized ultramafic rocks," Chemical Geology, vol. 257, no. 1-2, pp. 76-91, 2008.

[21] B. Y. Choi, S. T. Yun, K. H. Kim, H. S. Choi, G. T. Chae, and P. K. Lee, "Geochemical modeling of CO2-water-rock interactions for two different hydrochemical types of CO2-rich springs in Kangwon District, Korea," Journal of Geochemical Exploration, vol. 144, pp. 49-62, 2014.

[22] T. Critelli, G. Vespasiano, C. Apollaro, F. Muto, L. Marini, and R. De Rosa, "Hydrogeochemical study of an ophiolitic aquifer: a case study of Lago (Southern Italy, Calabria)," Environmental Earth Sciences., vol. 74, no. 1, pp. 533-543, 2015.

[23] T. Critelli, L. Marini, J. Schott et al., "Dissolution rates of actinolite and chlorite from a whole-rock experimental study of metabasalt dissolution from $2 \leq \mathrm{pH} \leq 12$ at 25 C," Chemical Geology, vol. 390, pp. 100-108, 2014.

[24] H. Hellevang, V. T. H. Pham, and P. Aagaard, "Kinetic modelling of $\mathrm{CO}_{2}$-water-rock interactions," International Journal of Greenhouse Gas Control, vol. 15, pp. 3-15, 2013. 
[25] K. L. Lecomte, A. I. Pasquini, and P. J. Depetris, "Mineral weathering in a semiarid mountain river: its assessment through PHREEQC inverse modeling," Aquatic Geochemistry, vol. 11, no. 2, pp. 173-194, 2005.

[26] D. Miriello, A. Bloise, G. M. Crisci, E. Barrese, and C. Apollaro, "Effects of milling: a possible factor influencing the durability of historical mortars," Archaeometry, vol. 52, no. 4, pp. 668$679,2010$.

[27] M. U. Sharif, R. K. Davis, K. F. Steele, B. Kim, T. M. Kresse, and J. A. Fazio, "Inverse geochemical modeling of groundwater evolution with emphasis on arsenic in the Mississippi River Valley alluvial aquifer, Arkansas (USA)," Journal of Hydrology, vol. 350, no. 1-2, pp. 41-55, 2008.

[28] G. Vespasiano, P. Notaro, and G. Cianflone, "Water-mortar interaction in a tunnel located in Southern Calabria (southern Italy)," Environmental and Engineering Geoscience, vol. 24, no. 3, pp. 305-315, 2018.

[29] C. Zhu, "Geochemical modeling of reaction paths and geochemical reaction networks," Reviews in Mineralogy and Geochemistry, vol. 70, no. 1, pp. 533-569, 2009.

[30] S. Mazzoli and M. Helman, "Neogene patterns of relative plate motion for Africa-Europe: some implications for recent central Mediterranean tectonics," in Active Continental Margins - Present and Past, pp. 464-468, Springer, Berlin, Heidelberg, 1994.

[31] C. Monaco, L. Tortorici, and W. Paltrinieri, "Structural evolution of the Lucanian Apennines, southern Italy," Journal of Structural Geology, vol. 20, no. 5, pp. 617-638, 1998.

[32] R. W. H. Butler, S. Corrado, S. Mazzoli et al., "Time and space variability of «thin-skinned» and «thick-skinned» thrust tectonics in the Apennines (Italy)," Rendiconti Lincei, vol. 11, no. 1, pp. 5-39, 2000.

[33] S. Critelli, F. Muto, V. Tripodi, and F. Perri, "Relationships between lithospheric flexure, thrust tectonics and stratigraphic sequences in foreland setting: the southern Apennines foreland basin system, Italy," in New Frontiers in Tectonic Research - At the Midst of Plate ConvergenceNew Frontiers in Tectonic Research - At the Midst of Plate Convergence, U. Schattner, Ed., pp. 121-170, InTech Open Access Publisher, 2011.

[34] S. Critelli, F. Muto, V. Tripodi, and F. Perri, "Link between thrust tectonics and sedimentation processes of stratigraphic sequences from the southern Apennines foreland basin system, Italy," Rendiconti Online della Società Geologica Italiana, vol. 25, pp. 21-42, 2013.

[35] J. P. Van Dijk, M. Bello, G. P. Brancaleoni et al., “A regional structural model for the northern sector of the Calabrian Arc (Southern Italy)," Tectonophysics, vol. 324, no. 4, pp. 267$320,2000$.

[36] F. Corbi, G. Fubelli, F. Lucà et al., "Vertical movements in the Ionian margin of the Sila Massif (Calabria, Italy)," Bollettino della Societa Geologica Italiana, vol. 128, no. 3, pp. 731-738, 2009.

[37] E. Turco, R. Maresca, and P. Cappadona, "La tettonica pliopleistocenica del confine calabro-lucano: modello cinematico," Memorie della Societa Geologica Italiana, vol. 45, pp. 519-529, 1990.

[38] S. Catalano, C. Monaco, L. Tortorici, and C. Tansi, "Pleistocene strike-slip tectonics in the Lucanian Apennine (southern Italy)," Tectonics, vol. 12, no. 3, pp. 656-665, 1993.

[39] M. Schiattarella, "Quaternary tectonics of the Pollino Ridge, Calabria-Lucania boundary, southern Italy," in Geological
Society, vol. 135, pp. 341-354, Special Publications, London, 1998.

[40] C. Tansi, F. Muto, S. Critelli, and G. Iovine, "Neogene-Quaternary strike-slip tectonics in the central Calabrian Arc (southern Italy)," Journal of Geodynamics, vol. 43, no. 3, pp. 393414, 2007.

[41] A. IANNACE, S. VITALE, M. D'ERRICO et al., "The carbonate tectonic units of northern Calabria (Italy): a record of Apulian palaeomargin evolution and Miocene convergence, continental crust subduction, and exhumation of HP-LT rocks," Journal of the Geological Society, vol. 164, no. 6, pp. 1165-1186, 2007.

[42] R. Selli, "Sulla trasgressione del Miocene nell'Italia meridionale," Museo Geologico" Giovanni Capellini", vol. 24, pp. 154, 1957.

[43] E. Patacca, R. Sartori, and P. Scandone, "Tyrrhenian basin and Apennines. Kinematic evolution and related dynamic constraints," in Recent Evolution and Seismicity of the Mediterranean Region, E. Boschi, Ed., pp. 161-171, Springer, Dordrecht, 1993.

[44] G. Bonardi, F. O. Amore, G. Ciampo, P. de Capoa, P. Miconnet, and V. Perrone, "Il complesso Liguride Auct.: Stato delle conoscenze e problemi aperti dulla sur evoluzione pre-Appenninica ed i suoli rapporti con l'Arco Calabro," Memorie della Società Geologica Italiana, vol. 41, pp. 17-35, 1988.

[45] E. Patacca and P. Scandone, "Geology of the southern Apennines," Bollettino della Società Geologica Italiana, vol. 7, pp. 75-119, 2007.

[46] F. Matano, S. Critelli, M. Barone, F. Muto, and S. Di Nocera, "Stratigraphic and provenance evolution of the Southern Apennines foreland basin system during the Middle Miocene to Pliocene (Irpinia-Sannio successions, Italy)," Marine and Petroleum Geology, vol. 57, pp. 652-670, 2014.

[47] C. Monaco, "Pleistocene strike-slip tectonics in the Pollino mountain range (Southern Italy)," Ann. Tecton. 8/2, 100-112, 1993.

[48] G. Cello and S. Mazzoli, "Apennine tectonics in southern Italy: a review," Journal of Geodynamics, vol. 27, no. 2, pp. 191-211, 1998.

[49] F. Muto, V. Spina, V. Tripodi, S. Critelli, and C. Roda, "Neogene tectonostratigraphic evolution of allochthonous terranes in the eastern Calabrian foreland (southern Italy)," Italian Journal of Geosciences, vol. 133, no. 3, pp. 455-473, 2014.

[50] S. Critelli, F. Muto, F. Perri, and V. Tripodi, "Interpreting provenance relations from sandstone detrital modes, southern Italy foreland region: stratigraphic record of the Miocene tectonic evolution," Marine and Petroleum Geology, vol. 87, pp. 47-59, 2017.

[51] C. Monaco and L. Tortorici, "Tectonic role of ophiolitebearing terranes in the development of the Southern Apennines orogenic belt," Terra Nova, vol. 7, no. 2, pp. 153-160, 1995.

[52] V. Allocca, F. Celico, P. Celico et al., "Note illustrative della Carta idrogeologica dell'Italia meridionale," in Istituto Poligrafico e Zecca dello Stato, ISBN 88-448-0215-5, P. Celico, P. Vita, G. Monacelli, and G. Tranfaglia, Eds., p. 211, con carte allegate, 2007.

[53] C. Apollaro, A. Buccianti, G. Vespasiano et al., "Comparative geochemical study between the tap waters and the bottled mineral waters in Calabria (Southern Italy) by compositional data 
analysis (CoDA) developments," Applied Geochemistry, vol. 107, pp. 19-33, 2019.

[54] C. Apollaro, G. Vespasiano, F. Muto, R. De Rosa, D. Barca, and L. Marini, "Use of mean residence time of water, flowrate, and equilibrium temperature indicated by water geothermometers to rank geothermal resources. Application to the thermal water circuits of Northern Calabria," Journal of Volcanology and Geothermal Research, vol. 328, pp. 147-158, 2016.

[55] G. Vespasiano, C. Apollaro, F. Muto, E. Dotsika, R. De Rosa, and L. Marini, "Chemical and isotopic characteristics of the warm and cold waters of the Luigiane Spa near Guardia Piemontese (Calabria, Italy) in a complex faulted geological framework," Applied Geochemistry, vol. 41, pp. 73-88, 2014.

[56] G. Vespasiano, C. Apollaro, F. Muto, R. De Rosa, E. Dotsika, and L. Marini, "Preliminary geochemical characterization of the thermal waters of the Grotta delle Ninfe near Cerchiara di Calabria (South Italy)," Rendiconti online della Società Geologica Italiana, vol. 39, pp. 130-133, 2016.

[57] G. Vespasiano, C. Apollaro, R. De Rosa et al., “The Small Spring Method (SSM) for the definition of stable isotope - elevation relationships in Northern Calabria (Southern Italy)," Applied Geochemistry, vol. 63, pp. 333-346, 2015.

[58] G. Vespasiano, L. Marini, C. Apollaro, and R. De Rosa, "Preliminary geochemical characterization of the thermal waters of Caronte SPA springs (Calabria, South Italy)," Rendiconti online della Società Geologica Italiana, vol. 39, pp. 138-141, 2016.

[59] V. Cotecchia, G. Nuzzo, A. Salvemini, and N. A. Ventrella, "Studi di geologia applicata ed idrogeologia finalizzati alla realizzazione della galleria di valico del Monte la Mula per l'Acquedotto dell'Abatemarco-Mezzafiumina," Geol. Appl. e Idrogeol, vol. 18, no. 1, pp. 451-489, 1983.

[60] D. Grassi, S. Grimaldi, F. Sdao, and G. Spilotro, "Idrogeologia dell'acquifero carbonatico di Madonna del Pollino (Basilicata)," Mem. Soc. Geol. It., vol. 51, pp. 975-988, 1996.

[61] C. Apollaro, V. Tripodi, G. Vespasiano et al., "Chemical, isotopic and geotectonic relations of the warm and cold waters of the Galatro and Antonimina thermal areas, southern Calabria, Italy," Marine and Petroleum Geology, vol. 109, pp. 469-483, 2019.

[62] C. Apollaro, A. Caracausi, M. Paternoster et al., "Fluid geochemistry in a low-enthalpy geothermal field along a sector of southern Apennines chain (Italy)," Journal of Geochemical Exploration, vol. 219, p. 106618, 2020.

[63] I. Fuoco, A. Figoli, A. Criscuoli et al., "Geochemical modeling of chromium release in natural waters and treatment by RO/NF membrane processes," Chemosphere, vol. 254, p. $126696,2020$.

[64] A. Figoli, I. Fuoco, C. Apollaro et al., "Arsenic-contaminated groundwaters remediation by nanofiltration," Separation and Purification Technology, vol. 238, p. 116461, 2020.

[65] M. Vardè, A. Servidio, G. Vespasiano et al., "Ultra-trace determination of total mercury in Italian bottled waters," Chemosphere, vol. 219, pp. 896-913, 2019.

[66] G. Vespasiano, G. Cianflone, A. Romanazzi et al., "A multidisciplinary approach for sustainable management of a complex coastal plain: the case of Sibari Plain (Southern Italy)," Marine and Petroleum Geology, vol. 109, pp. 740-759, 2019.

[67] S. Margiotta, G. Mongelli, V. Summa, M. Paternoster, and S. Fiore, "Trace element distribution and $\mathrm{Cr}$ (VI) speciation in $\mathrm{Ca}-\mathrm{HCO} 3$ and $\mathrm{Mg}-\mathrm{HCO} 3$ spring waters from the northern sector of the Pollino Massif, southern Italy," Journal of Geochemical Exploration, vol. 115, pp. 1-12, 2012.

[68] T. W. Wolery and C. Jove-Colon, "Qualification of thermodynamic data for geochemical modeling of mineral-water interactions in dilute systems," Sandia National Laboratories Report ANL-WIS-GS-000003 REV 01, Yucca Mountain Project, Las Vegas, Nevada, 2007.

[69] T. J. Wolery and S. A. Daveler, "EQ 6, a computer program for reaction path modeling of aqueous geochemical systems: theoretical manual, user's guide, and related documentation (version 7.0)," Report UCRL-MA-110662 PT IV, Lawrence Livermore National Laboratory, United States, 1992.

[70] M. C. Dichicco, S. Laurita, M. Paternoster, G. Rizzo, R. Sinisi, and G. Mongelli, "Serpentinite carbonation for CO2 sequestration in the southern Apennines: preliminary study," Energy Procedia, vol. 76, pp. 477-486, 2015.

[71] G. Rizzo, M. T. Cristi Sansone, F. Perri, and S. Laurita, "Mineralogy and petrology of the metasedimentary rocks from the Frido Unit (southern Apennines, Italy)," Periodico di Mineralogia, vol. 85, no. 2, 2016.

[72] J. Dousma and P. L. de Bruyn, "Hydrolysis-precipitation studies of iron solutions. I. Model for hydrolysis and precipitation from Fe (III) nitrate solutions," Journal of Colloid and Interface Science, vol. 56, no. 3, pp. 527-539, 1976.

[73] D. K. Nordstrom, L. N. Plummer, T. M. L. Wigley et al., “A comparison of computerized chemical models for equilibrium calculations in aqueous systems," in ACS Symposium Series, E. A. Jenne, Ed., pp. 857-892, 1979.

[74] C. A. J. Appelo and D. Postma, Geochemistry, Groundwater and Pollution, A.A. Balkema, Rotterdam, 1996.

[75] R. O. Fournier, "Silica in thermal waters: laboratory and field investigations," Proc. Int. l Symp. Hydrogeochemistry and Biogeochemistry, 1973pp. 122-139, Tokyo, 1973.

[76] D. K. Nordstrom, "Aqueous redox chemistry and the behavior of iron in acid mine waters," Proceedings of the Workshop on Monitoring Oxidation-Reduction Processes for Ground-water Restoration, 2002, pp. 43-47, Environmental Protection Agency. EPA/600/R-02/002, Dallas, Texas, April 25-27, 2000 Cincinnati, OH, 2002.

[77] G. A. Brook, M. E. Folkoff, and E. O. Box, "A world model of soil carbon dioxide," Earth Surface Processes and Landforms, vol. 8, no. 1, pp. 79-88, 1983.

[78] W. Pohl, "Comparative geology of magnesite deposits and occurrences," Monogr. Ser. Mineral deposits, vol. 28, pp. 113, 1989.

[79] W. Pohl, "Genesis of magnesite deposits—models and trends," Geologische Rundschau, vol. 79, no. 2, pp. 291-299, 1990.

[80] R. M. Garrels, "Genesis of some ground waters from igneous rocks," in Researches in Geochemistry, P. H. Abelson, Ed., vol. 2, pp. 406-420, Wiley, 1968.

[81] F. B. Tonani, K. Nagao, J. Moore, G. Natale, and T. Sperry, "Water and gas geochemistry of the Cove-Fort Sulphurdale geothermal system," Proceedings, Twenty-Third Workshop on Geothermal Reservoir Engineering, 1998Stanford University, Stanford, California, 1998.

[82] World Health Organization, Guidelines for Drinking-Water Quality: First Addendum to the Fourth Edition, 2017, https:// www.who.int/publications/i/item/9789241549950. 